\title{
العلاقة الارتباطية بين القيم الأخلاقية و التفكير الناقد والابتكاري لدى طلاب الصف الأول بالمرحلة الثانوية الثية
}

هناء عبر الله عبد الله البلتاجي

$$
\begin{aligned}
& \text { هدفت الدراسة الحالبة للكثف عن العلاقة بين القيم الأخلاقية وكلا من التفكبر الناقـــــ والتفكيـر } \\
& \text { الابتكاري لدى طلاب و طالبات الصف الأول بالمرحلة الثانوية العامة ، وبلغت عينة البحث (VMT) طالبًا } \\
& \text { وطالبة طبق علبهم مقياس القيم الأخلاقية (إعداد الباحثة، } 7 \text { ا ـ r) واختبار كاليفورنيا لمهـار ات التفكيـر }
\end{aligned}
$$

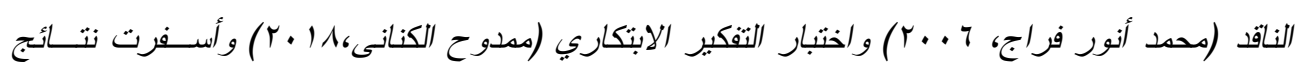

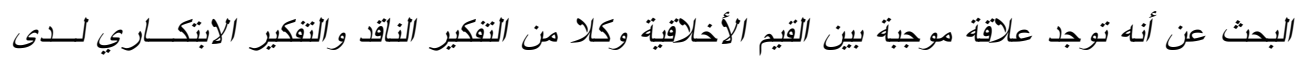

$$
\begin{aligned}
& \text { طلاب و طالبات الصف الأول بالمرحلة الثانوية العامة. }
\end{aligned}
$$

\section{Abstract:}

The current research aimed at determining the relation among the Moral values and both of the Critical thinking and Creative thinking of the first grade students of the secondary stage. The research sample included (733) students of about (311) male and (422) female. The researcher used the description method to collect the required information and data for the research. The researcher used the moral values measurement (prepared by the researcher), and California test of the critical thinking skills (prepared by: Mamdoh Elkinani, 2018). The results of the research revealed that there was a positive relationship between ethical values and both critical thinking and innovative thinking among students and students in the first grade of the secondary school.

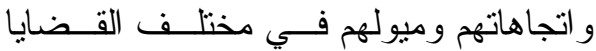

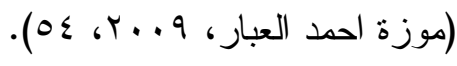

$$
\begin{aligned}
& \text { فالأزمة في القيم الأخلاقيــة و التــي }
\end{aligned}
$$

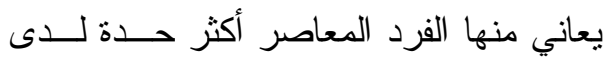

$$
\begin{aligned}
& \text { جيل الثباب الذي يعاني غموضناً في الهويـــة } \\
& \text { وضياعاً في الأهداف خاصة بعد الأزمــات } \\
& \text { و الهز ات الاجنماعية و السياسية العميقة التـي } \\
& \text { عصفت بالعالم المعاصر ، ليجد الثباب نفسه }
\end{aligned}
$$

$$
\begin{aligned}
& \text { ينشأ الطلاب اليوم في عصر تتعرض } \\
& \text { فيه المجتمعات المحافظة للتغير ات العالميــة } \\
& \text { في ظـلـل الحــضــارة المعاصــرة، و التقـــدم } \\
& \text { التكنولوجي الذي يميز أنماط الحياة ووسائلها } \\
& \text { ومنطلباتها، فوقع الطلاب فريـسـة الــصر اع } \\
& \text { بين القيم الإسلامية و العــادات و الــسلوكيات } \\
& \text { المستوردة، مما أصـــابهم بـــالحيرة و القلــقت } \\
& \text { و التيه، و الذي انعكس على أنماطهم السلوكية }
\end{aligned}
$$


عالية تشكر هم عليها الأجيال القادمة وتقــدم

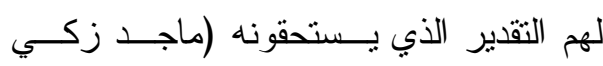

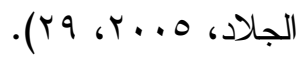

ويعرف الابتكار بأنــهـه مــزيج مــن

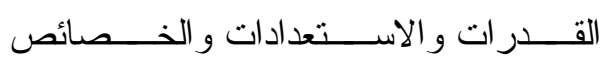
الثخصية التي إذا ما وجدت بيئــة مناســبة

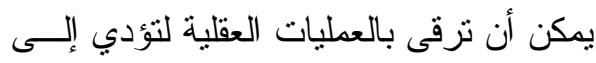

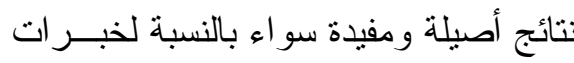

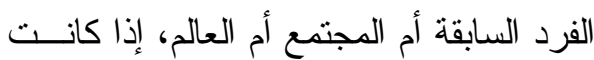
النتائج من مستوى الاختر اقات الابتكارية في أحد ميادين الإنسـسانية ( فتحسي جــروان، . (70 r... T

فالمبتكر في الكبر هو شخص تربـى

في مرحلة طفولته بطريقة إيداعية، فكما نعلم

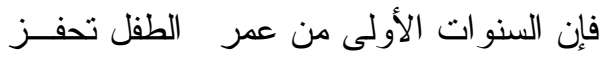

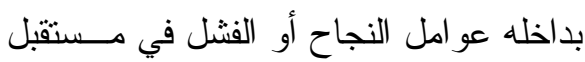

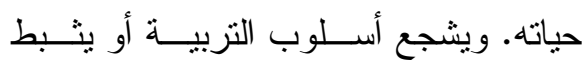

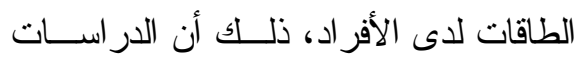

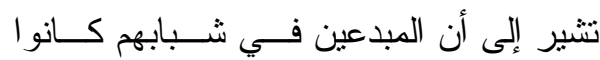

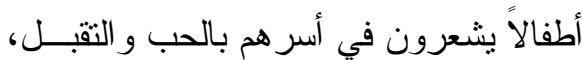
وكانو ا يتمتعون بقدر معقول مــن المبــادأة

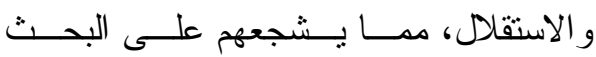
والاستكثاف كما كانو ا ينالون التشجيع على

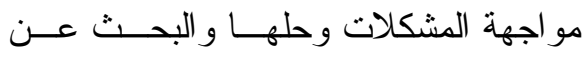

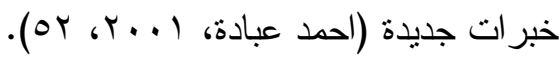
بينما بــرى ) Antoniou, 2015 164أنه لا يوجد علاقة بين القيم الأخلاقيـــة
موز عاً بين أهداف وغايات متعددة وما يتبعها

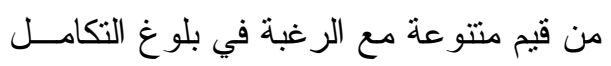

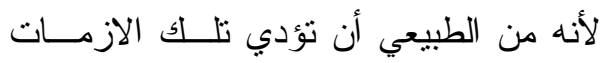
الحادثة في المجنمع المصري إلى تغيير فـى لـى لــي

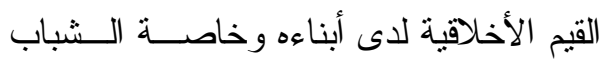
منهم (فايزة أنور شكري، rr.0، . . r).

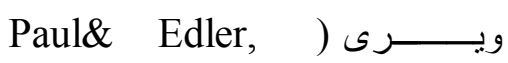

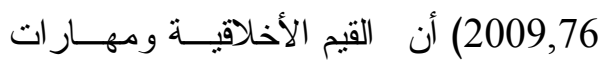

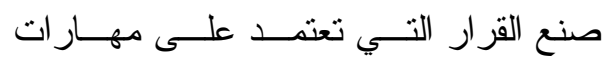
كالاستتناج و الاستتباط من مهار ات التفكيــر

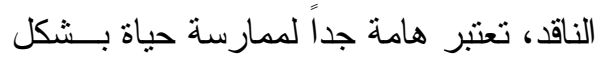
أفضل تقوم على المبادئ الأخلاقية. كما برى (Fsko, 1994 ( 56 أن التربية الأخلاقية

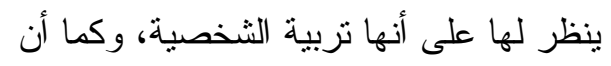

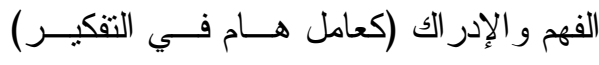
ضروريان لإدر الك المشاكل التي تعاني منها الثخصية. ولما كان حرص المؤسسات التعليمية بمؤسساتها على النهوض بالمستويات الفكرية

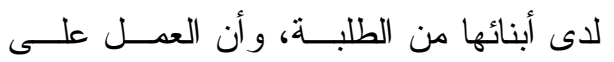

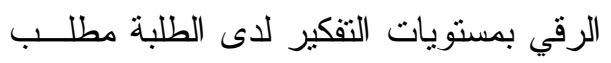

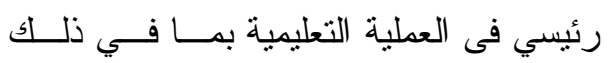

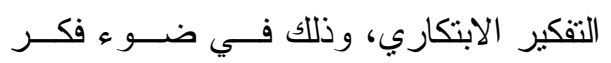

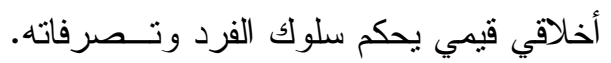

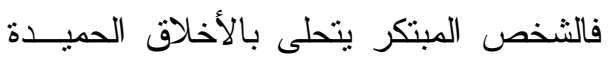

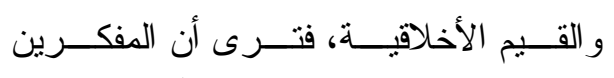

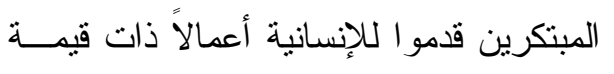


ويمكن تحديد مشكلة البحــث مــن خــلال

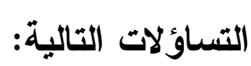

1 - هل توجد علاقة بين القيم الأخلاقيــة،

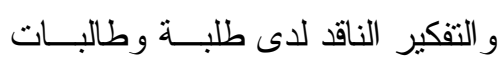

الصف الأول الثانوي؟

r - هل توجد علاقة بين القـيم الأخلاقيـــة و التفكير الابتكاري لدى طلبة وطالبات

الصف الأول الثانوي؟

أهداف البحث: - (الهف

يهذف البحث الحالي إلى:

1- الكثف عن العلاقة بين القيم الأخلاقية

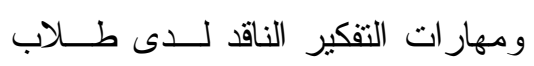

الصف الأول بالمرحلة الثانوية.

r- الكثف عن العلاقة بين القيم الأخلاقية

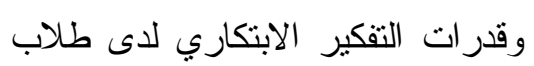

$$
\text { الصف الأول الثانوي. }
$$

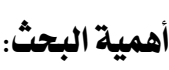

يستمد البحث الحالي أهميته من:

1- التعرف على مستوى القيم الأخلاقيـــة

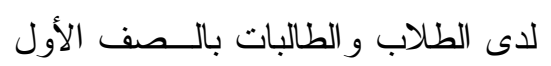

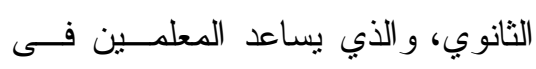

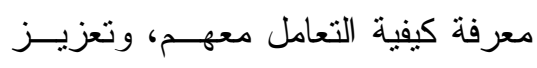

جو انب الإيجاب أو التميز لديهم، وتتمية معثية وتعزية

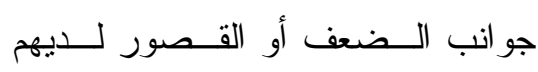

بأساليب وطرق تنتاســب مــع قــيمهم

الأخلاقية.
و التفكير الابتكاري، وأنه توجد علاقة إيجابية بين الخداع أو الغش و الابتكار خصوصاً فيما

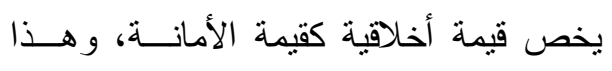
خلاف ما هو شائع.

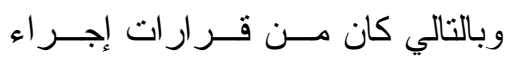
البحث الحالي ما وجدته الباحثة من التعارض كن ونتائج الدراسات السابقة في العلاقة بين القيم الأخلاقية و التفكير الابتكاري، ورأت الباحثة ضرورة بحث تلك العلاقة.

وفيما يخص علاقة القــيم الأخلاقيــة

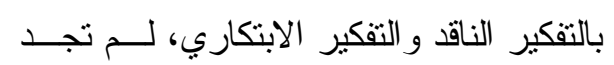

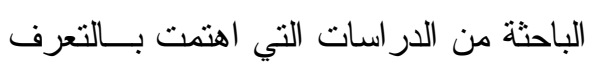
على العلاقة بينهم، وكان التزكيز الأكبر على لـى لنى

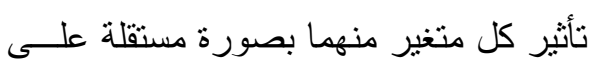

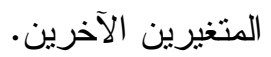

ويتضح مما ســـق اخــتلاف نتــائج

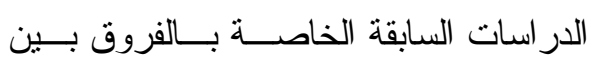
الجنسين في القيم الأخلاقية، وعدم وجود من

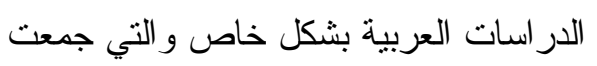

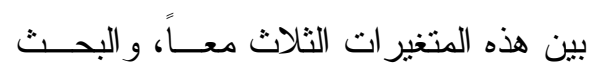

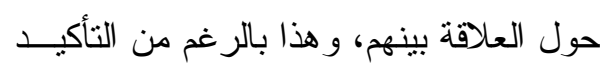

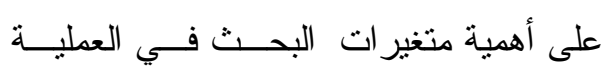
التعليمية و الاتجاهات الحديثة لتطوير وزيادة فاعلية الأفر اد في المجتمع، ومن هنا يــذهب

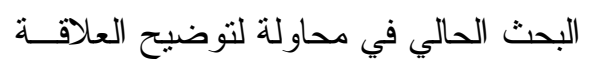

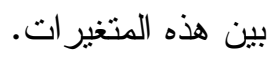


V-وضع بر امج ارشادية قائمة على القـيم الأخلاقية ذات العلاقة بمهار ات التفكير الناقد وقدر ات التفكير الابتكاري.

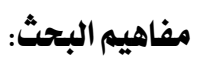

أولا: القيم الأخلاقية Moral Values: تعريف القيم الأخلاقية:

ويعـرف Menzel \& Bögeholz

(2010,201) القيمة بأنها صورة داخلية أو خارجية للغايات تميز الأفراد أو الجماعـات

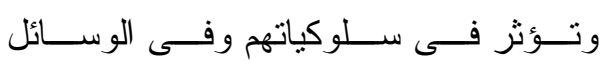
و الإجر اءات التي يستخدمونها. وتتحدد القيم الأخلاقية كما يلي:

الصدق Credibility: يشير الـى

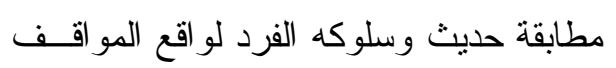
و الاشياء وحقيقتها.

الأمانة:Honesty تعني وفاء الفــرد

برد الأثياء التي تكون خاصة بالأخرين.

التسامع: Tolerance يشير إلـى

العفو عن الناس، ومقابلة الإساءة بالإحسان،

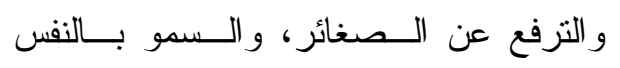
البشرية البز

التعاون: Cooperation تعنــي أن

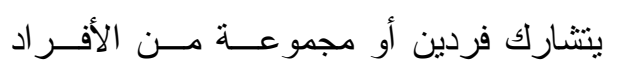

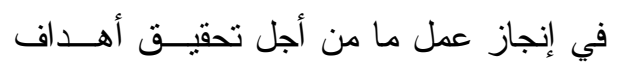

r-كذلك تكمن أهمية البحث الحـالي فـي محاولة إثراء البحوث التربوية و النفسية

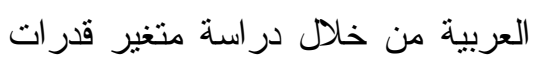

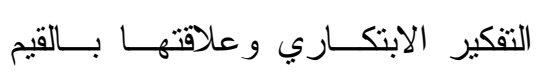

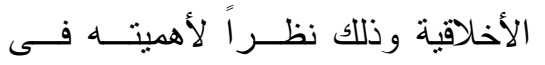

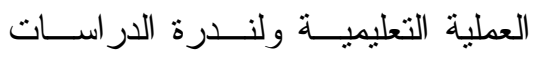
العربية الحديثة التي نتاولهما معاً. r-عدم وجود در اسة من الدراسات العربية

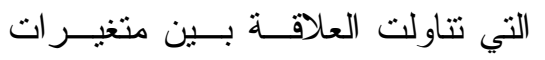

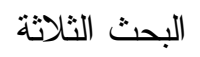
ع-تتاول البحث عينة بحثية مـن طــلاب وطالبات الصف الأول بالمرحلة الثانوية

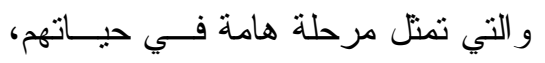
يحتاجون فيها الى معرفة المهار ات التي هني تساعدهم على التفكير الناقد و القــدرات

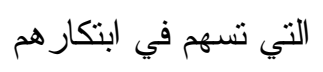
0-تحديد فئة طلاب الصف الأول الثانوي

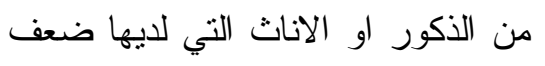

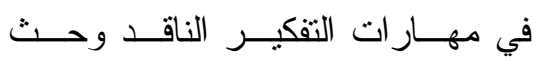
المسئولين و الباحثثن لعمل بر امج لتنمية جو انب القصور لديها. 1-تحديد فئة طلاب الصف الأول الثانوي من الذكور أو الاناث التي لديها ضعف

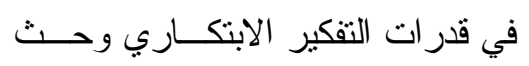
المسئولين و الباحثين لعمل بر امج لتتمية جو انب القصور لديها. 
ه- القــيم ذات ثبــات و اســتقر ار نفـسـي و اجتماعي نسبي، لكن هذا الثبات يسمح دات لواري

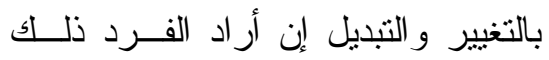

$$
\text { بعزيمة صادقة. }
$$

1- يتميز بعض الأفر اد بقيم فردية خاصـــة

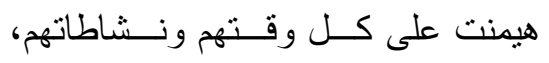
ودو افعهم وسلوكهم. وقد كان من هؤلاء

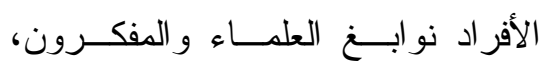
المخترعون، الفنانون و القادة العسكريون ألّنين استفادت منهم المجتمعات الإنسانية في شتى المجالات.

ثانياً: التفكير الناقد Critical Thinking:

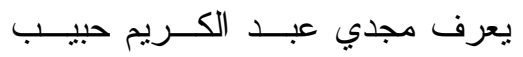

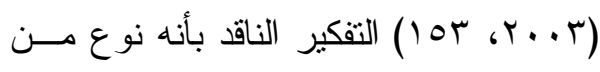
التفكير الهادف الذي يتكون من مجموعة من القدرات و المهار ات التي تتمنل فـــي القــدرة

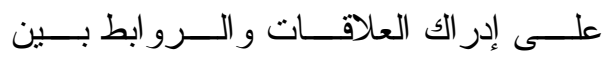
المعارف، و القدرة علــى التحليــل و اتخـــاذ

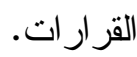

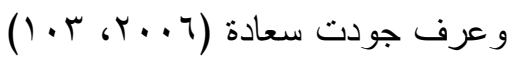

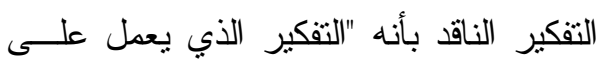
تقييم نفسه بنفسه، و أنه القدرة على التفكيـر

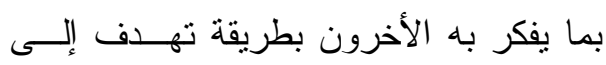

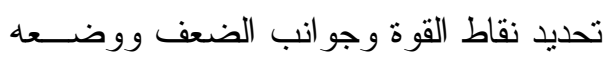

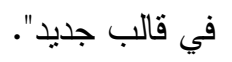

التعاطف Empathy: يقصد به تفهم

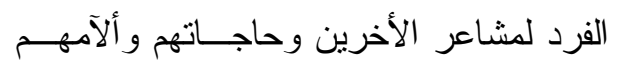
بالإضافة الى تجاوبه معهم.

الإيثار Altruism: يشير الى تفضيل

مصلحة الأخرين على المصلحة الشخصية.

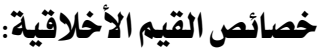

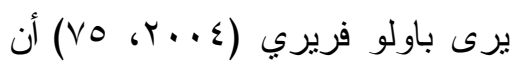

مفهوم القيم من المفاهيم المتـشعبة، و التــي ديري

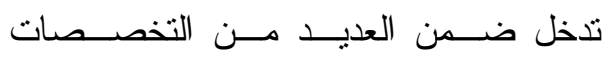

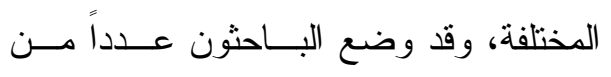

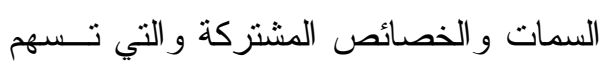

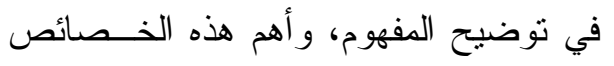
ما يلي:

1- القيم أساسية في حياة كل إنسان سـوي،

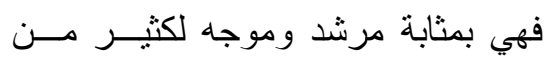

$$
\text { النشاط الحر الإر ادي للإنسان. }
$$

r- القيم تصطبغ بالصبغة الاجتماعيــة، أي أنها تتطلق من إطار اجتماعي.

ب- القيم مكتسبة، إذ يتعلمهــــا الفــرد عــن

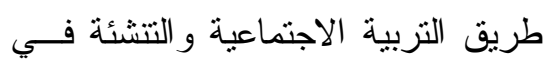

$$
\text { نطاق الجماعة. }
$$

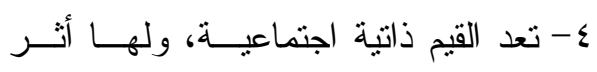

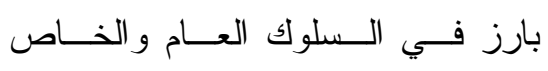

للفرد و الجماعة، وفى تحديد كثير مـنـ

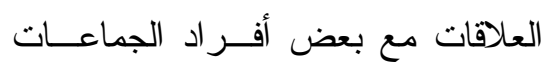
الأخرى. 


$$
\text { تـدال }
$$

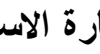

الاســـتقرائي Inductive Inference يقصد بها الدلالات والاحكام التـي Skill: يصدرها الثخص بعد الرجوع الى مواقـــ أو أحداث.

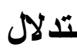

\section{Deductive Inference}

هي عملية تفكير منظمة تتجم عنهــا Skill:

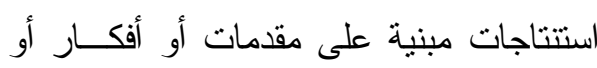

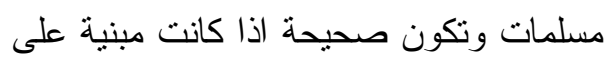

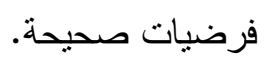

استر اتيجيات وبرامج لتنمية التفكير الناقد: تستتد العوامل المؤثزة فــي التقكيــر

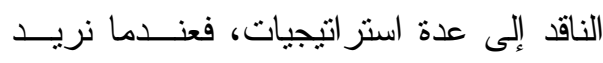

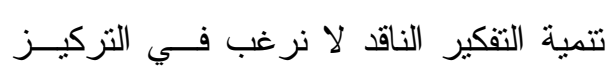

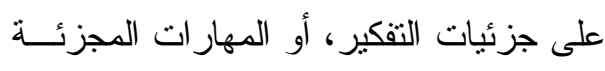

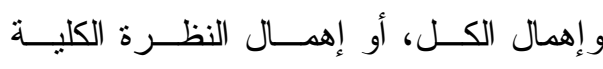
الثاملة، ومن هذه الاستر اتيجيات:

$$
\text { • - الاستر اتيجية العاطفية: }
$$

تَهذف هذه الاستر اتيجية إلــى تتميـــة

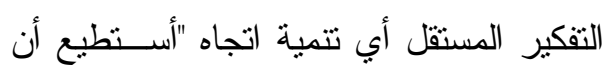

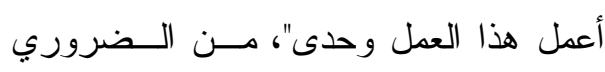

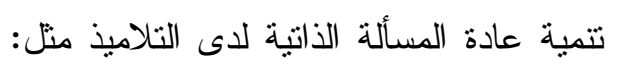

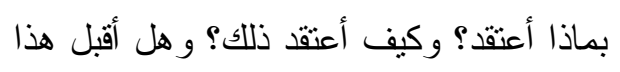
الاعتقاد فعلاًٌ وحتى يتمكن الأطفال من تعلم

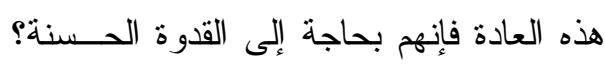

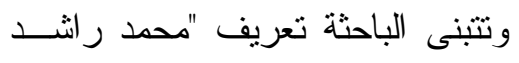

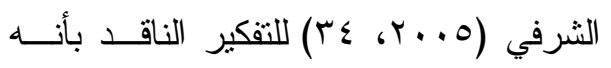
قدرة الفرد على الفحص الدقيق للمو اقف التي

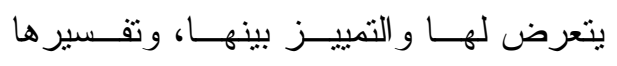

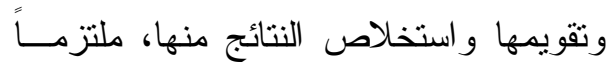

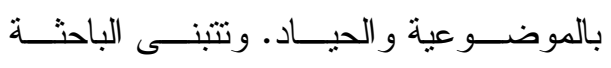

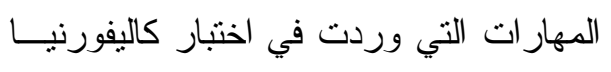

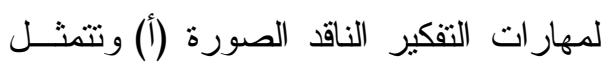
مهارة التحليـل Analyeis Skill ويشير إلى قدرة الفرد على الفهـــ و التعبيــر

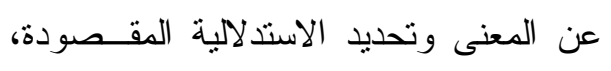
و هي فحص واختبار الأفكار ونتبع المناقتشات وتحليلها الى عناصر وتصنيفها.

مهارة التقويم Evaluation Skill:

ويعني قدرة الفرد علـى تقيــيم مــصداقية

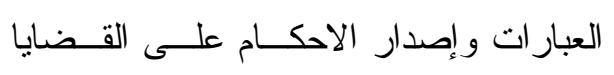

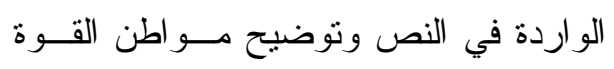
و الضعف في ضوء الأدلة المناحة.

مهارة الاستدلال Inference Skill: بتمنل في قدرة الفرد على ممارسة مجموعة

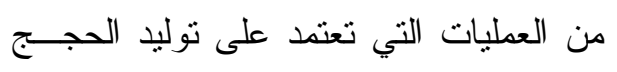

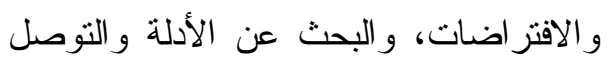

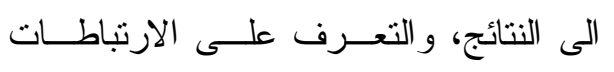
و العلاقات السببية. 
المهمة الأخرى التــي تفتـرض أن أنـشطة

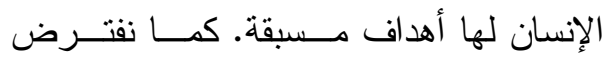
وجود أسباب وطرق لتتفيذها. ونوجد غالبــاً

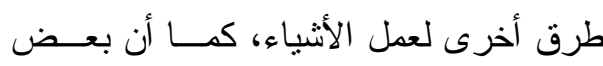
هذه الطرق أفضل من بعض، إن الطفل الذي لُعلي

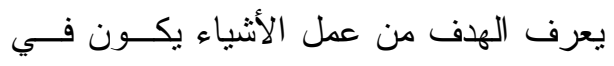

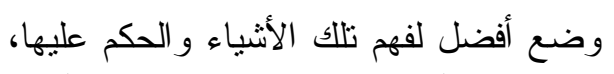

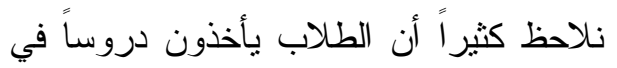

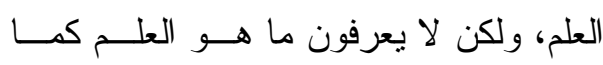

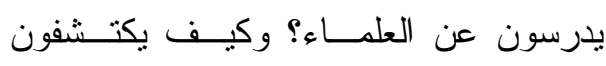

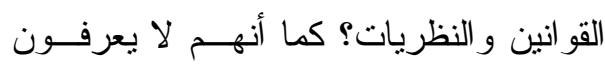
كيف يطرح العلماء الأسئلة؟ (محمد عـادل

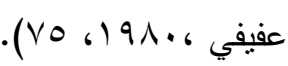
- - استر اتيجية التعرف على الأسباب:

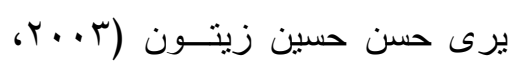

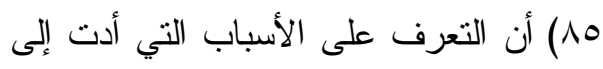

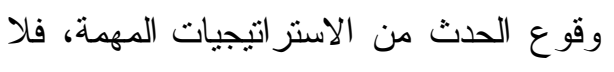

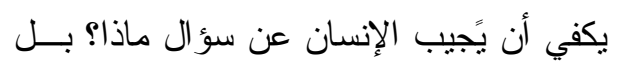
ينبغي أن يجيب عن سؤ ال لماذا؟ أيضاً. - - استر اتيجية التقويم:

إن القدرة على التقويم من العمليــات

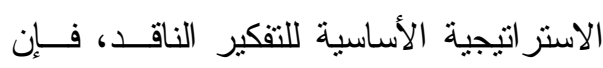

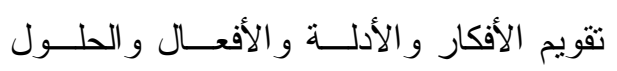
و المجادلات أمر هام، وتتضمن عملية التقويم

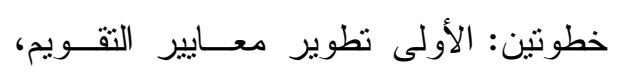

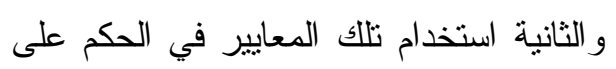
الأثياء.
يحتاج الأطفال إلـى رؤيـــة مــن يفكـرون باستقلالية إذا أردنا أن ننمي لــديهم التفكيـــر

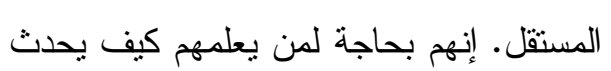

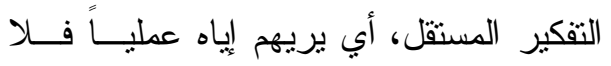
يكفي أن يتعــرف الــشخص علــى أفكـاره

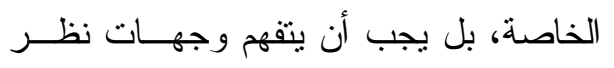

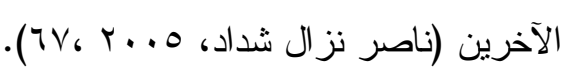
• - استر اتيجية التبصر والتعمق:

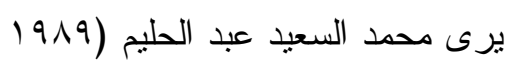

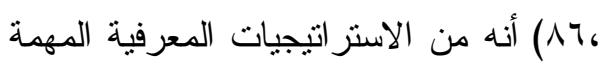

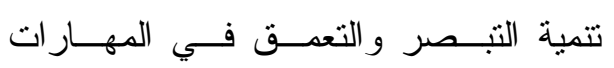
الميكانيكية وعدم الاكتفاء بأن يؤديها التلاميذ دون وعى وإدر الك عميقين بها. فإن ممارسة

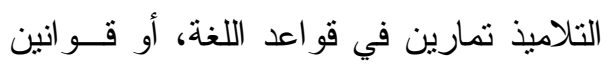

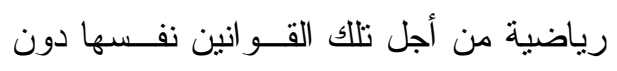

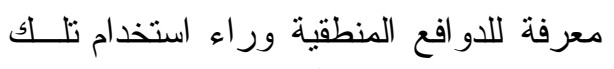

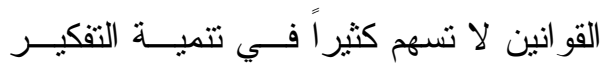

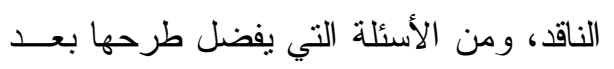

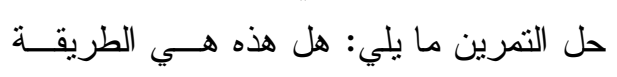

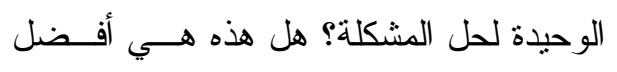

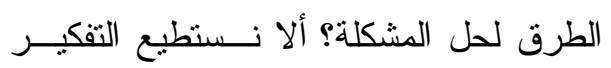
بطريقة أخرى؟ أي الطرق أفضل؟ ولماذا؟ • - استر اتيجية اكتثاف الأهداف:

يجب أن يعرف الطــلاب أن هنـــاك

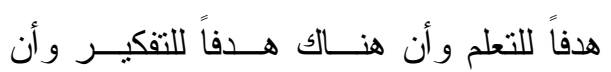

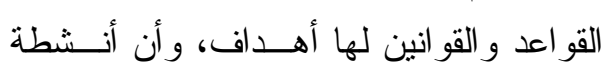

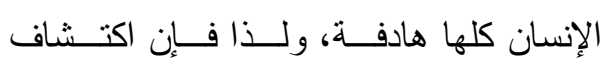
الأهداف الضمنية هي إحدى الاســتراتيجيات 
• - استر اتيجية التعرف على المترتبات:

ما هي المترتبات على هذا المعيــار؟

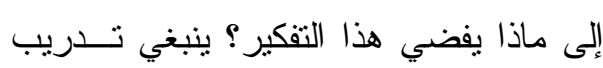

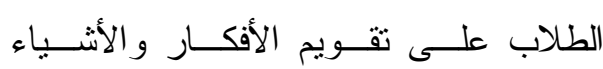

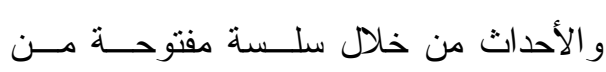

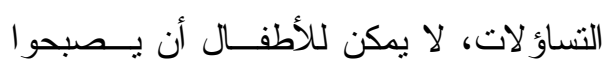

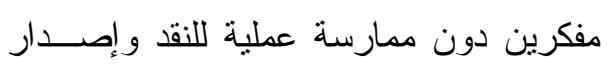

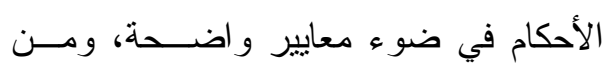

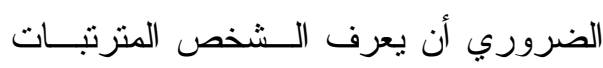

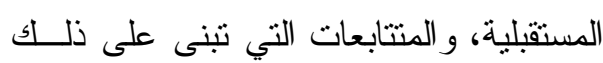
الشيء أو القرار، أو الفكرة أو الحدث (سعاد

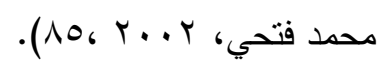

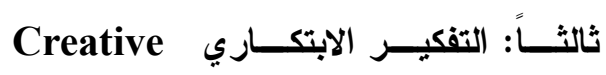
:Thinking

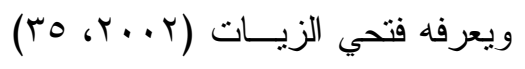

بأنه "توظيف عقلي معرفي ذا طبيعة انفعالية دافعية في ظل مناخ نفسي اجتماعي لإنتــاج شيء جديد ذا معنى ومغزى يتصف بالأصالة

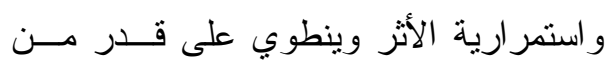

الجدة و الطلاقة و المرونة و إتقان التفاصيل".

ويــضيف Purton \& Bun

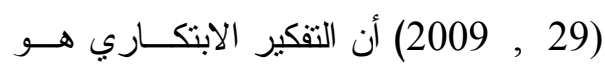

تفكير قائم على الفهم، ويشتمل على الطلاقـــة

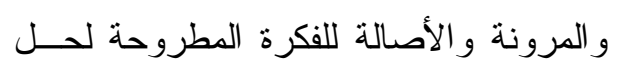

مشكلة ما.
عندما يتحول الطفل إلى مفكر ناقـــ

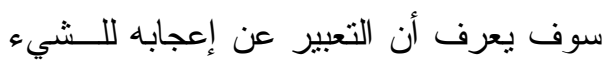
لا يكفي للحكم على صحة ذلك الثيء، و لابد

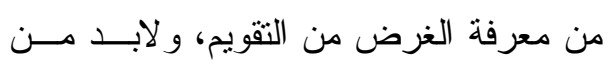
معرفة معايير التقويم، كما ينبخــي اســتخدام

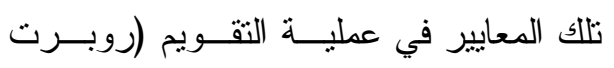

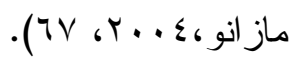
• - استراتيجية التعرف على المعايير :

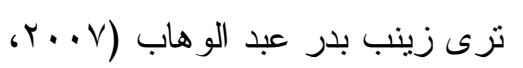

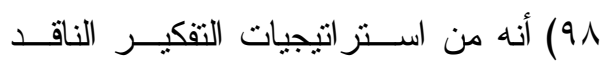

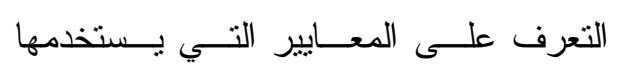

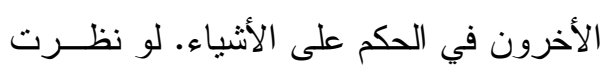

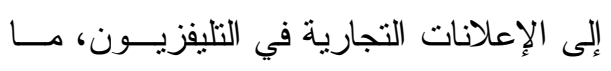
هو الانطباع الذي تأخذه عنها؟ لماذا نتشرى

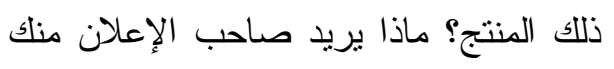

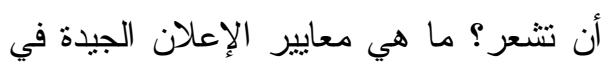
رأيك؟ و إذا نظرت إلى الأخبار في التليفزيون الإعان

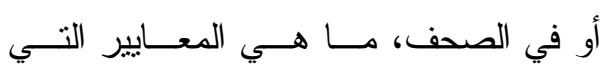

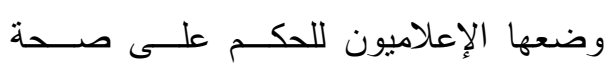
الأنباء؟ وما هي المعايير التي لم يستخدموها وينبغي عليهم استخدامها؟ وما هي المعسايير

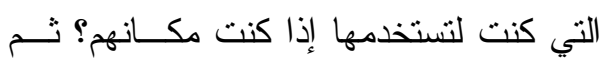
تأتي الخطوة الثانية، فبعد وضـــع المعـايير

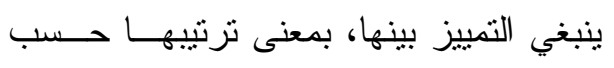

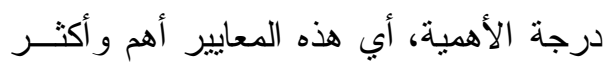

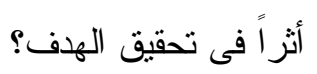




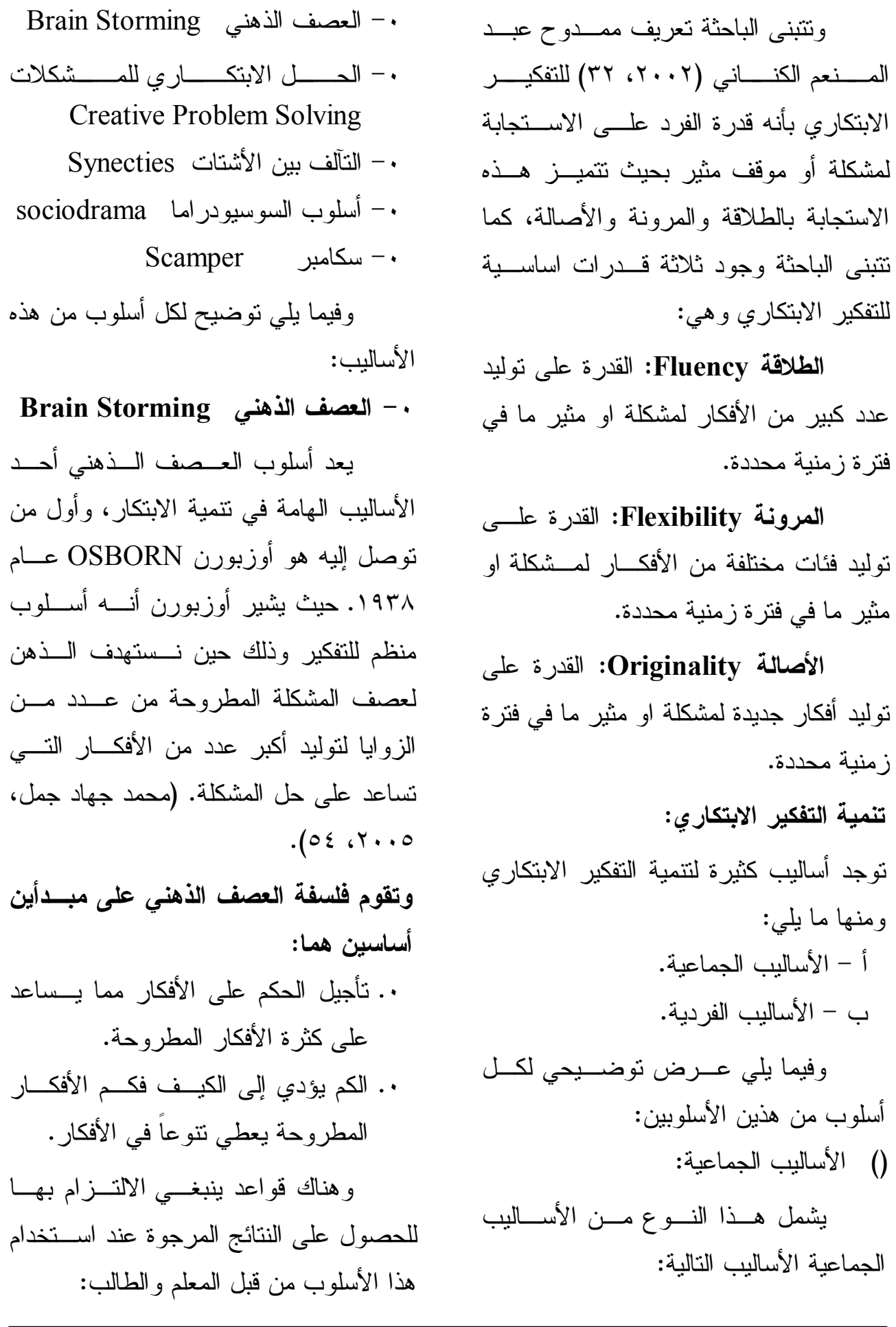




$$
\begin{aligned}
& \text { وفيما يلي عرض توضيحي لكل أسلوب من }
\end{aligned}
$$

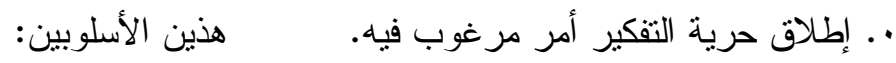

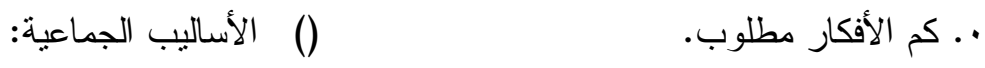

$$
\begin{aligned}
& \text { •. المزج بين الأفكار أو البناء على أفكار يشمل هذا النوع من الأســاليب الجماعيــة } \\
& \text { الآخرين وتحسينها (صلاح الدين عرفه، الأساليب التالية: } \\
& \text { Brain Storming العصف الذهني - - }
\end{aligned}
$$

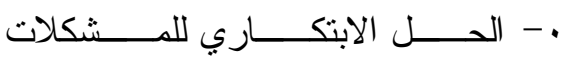

$$
\begin{aligned}
& \text { Creative Problem Solving } \\
& \text {. }(\varepsilon \cdot V \text {. Y . T } \\
& \text { Creative الحل الابتكاري للمشكلات - . } \\
& \text { Problem Solving } \\
& \text { Synecties التآلف بين الأشتات - . } \\
& \text { sociodrama أسلوب السوسيودر اما - . } \\
& \text { Scamper سكامبر - . }
\end{aligned}
$$

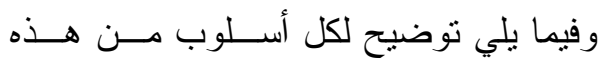

$$
\begin{aligned}
& \text { الأساليب: وفيا لئي } \\
& \text { يعد أسـلـوب العـصف الــذهني أحسد } \\
& \text { الأساليب الهامة في تتمية الابتكار، وأول }
\end{aligned}
$$

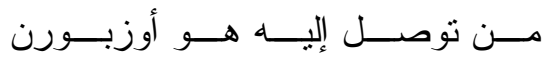

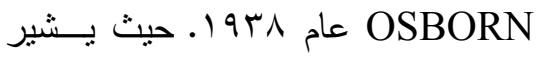

$$
\begin{aligned}
& \text { أوزبورن أنه أسلوب منظم للتفكير وذللك } \\
& \text { حين نستهدف الذهن لعـصف المـشكلة }
\end{aligned}
$$

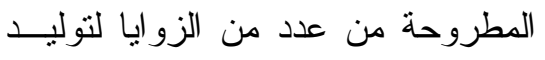

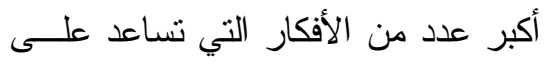

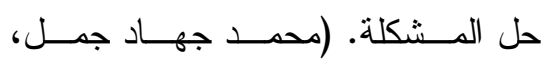

$$
\begin{aligned}
& .(0 \leq 6, . .0 \\
& \text { ويذكر" صلاح الدين عرفــه (0. . ب. } \\
& \text { تمان أنه أسلوب يهتم باستمطار أفكار تلقائية } \\
& \text { تتطلق بحرية دون نقــــ أو تقيــد وتحسـاول } \\
& \text { • . . ضرورة تجنب النقد. } \\
& \text { هو أسلوب يعتمــد علــى صــياغة } \\
& \text { المشكلة و التفكير في أبعادها وحلولها بطريقة } \\
& \text { غير مألوفة من خلال خلق الأفكار و الحلول }
\end{aligned}
$$

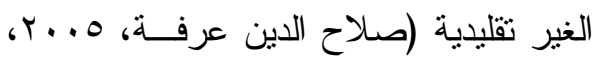

$$
\begin{aligned}
& .(1 \vee 9-1 \vee \wedge \\
& \text { Synecties التآلف بين الأثتات - } \\
& \text { ابتكــر "جـوردون Gordon" هــــه }
\end{aligned}
$$

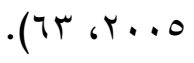

$$
\begin{aligned}
& \text { تنمية التفكير الابتكاري: }
\end{aligned}
$$

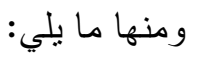

$$
\begin{aligned}
& \text { أ - أ - الأساليب الجماعية. }
\end{aligned}
$$

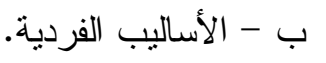




$$
\begin{aligned}
& \text { ت.إثارة تفكير التلاميــذ بعـض الأســـلة } \\
& \text { و الاستفسار ات. } \\
& \text { ث.يمارس التلاميذ حرية التفكير وطــرح } \\
& \text { التفسير ات و الحلول المختلفة. } \\
& \text { ج. تسجيل وتصنيف الإجابـات وتـشجيع } \\
& \text { التلاميذ على الربط بينها مما بساعد فى ونى } \\
& \text { الحصول على أفكار جديدة ومبتكرة. } \\
& \text { ح. يتم تقويم الأفكار كلها، و المقدمسـة مسنـ }
\end{aligned}
$$

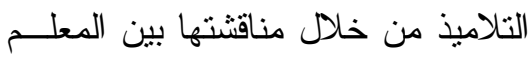

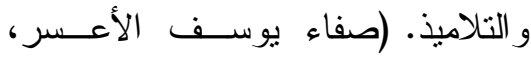

$$
\begin{aligned}
& \text {. (VT, T. . . }
\end{aligned}
$$

reative بالحل الابتكاري للمشكلات

Problem Solving

هو أســلوب يعتمــد علــى صـــياغة

المشكلة و التقكير في أبعادها وحلولها بطريقة

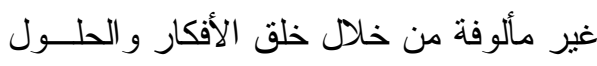

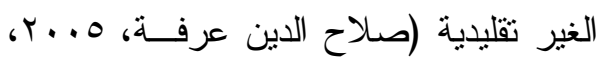

$$
\text { . () } \vee 9-1 \vee \wedge
$$

يقوم هذا الأسلوب على مجموعـــة الأفكــار الأساسية التالية كالأسلوب الإجر ائي:

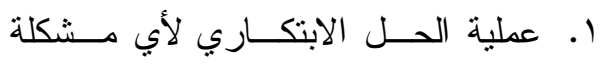
تتضمن ثلاث عمليات متعاقبة ومتذاخلة أحياناً وهي: أ. ملاحظة المشكلة أو الإحاطة بجوانبه

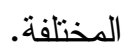

الإحاطة بأبعاد الموضوع الذي يــدرس، ثـــ

بعد ذلك يتم عرض وترتيب الأفكار ونقـــدها وتثتيت أكثر ها ملائمة.

وتقوم فلسفة العصف الذهني على مبـــأين

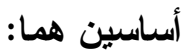
ا. تأجيل الحكم على الأفكار مدــا يـسـاعد هما: على كثرة الأفكار المطروحة.

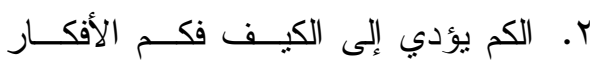
المطروحة يعطي نتو عاً في الأفكار .

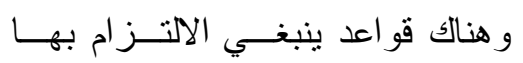
للحصول على النتائج المرجوة عند استخدام هذا الأسلوب من قبل المعلم و الطالب: ا ـ ضرورة تجنب النقد. r. إطلاق حرية التفكير أمر مرغوب فيه. r. - ب. كم الأفكار مطلوب. ع. المزج بين الأفكار أو البناء على أفكـار الآخرين وتحسينها (صلاح الدين عرفه،

$$
\text { . }(\varepsilon \cdot V \text {. Y . . Y }
$$

ويعتبر أسلوب العصف الذهني مسن

أساليب نتمية التفكير الابتكاري جماعيـاً، إلا

$$
\text { أنه يحتاج للتدريب الفردي أيضاً. }
$$

ويمكن تطبيق أسلوب العصف الذهني داخل حجرة الدر اسة على النحو التالي:

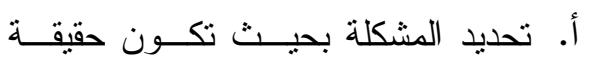
وتحظى باهتمام وتتاسب مسنو ياتهم. ب. تقسيم التلاميذ إلى مجمو عات صغيرة. 


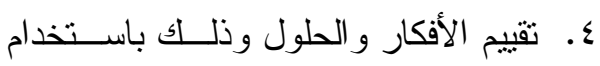

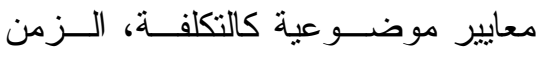

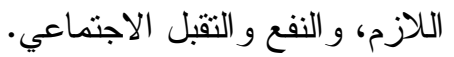

$$
\begin{aligned}
& \text { •. . الإعداد لوضع أفضل الحــــول موضــع }
\end{aligned}
$$

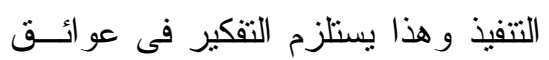

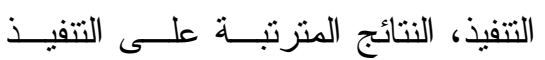

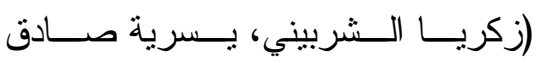

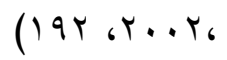

$$
\begin{aligned}
& \text { وأكدت در اسة (عباس أديبـي، ل ... Y، } \\
& \text { ه . 1) على فاعلية برنامج قائم على أسلوب } \\
& \text { حل المشكلة الابتكارية في تتميــة التفكيــر } \\
& \text { الابتكاري لحل بعض المشكلات المستقبلية. }
\end{aligned}
$$

\section{r-التآلف بين الأشتات}

ابتكــر "جــوردون Gordon" هــذهـ

Synecties الطريق عــام الو 197 وكلمــة يونانية الأصل وتعني ربط العناصر المناسبة

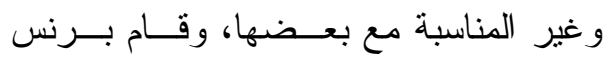

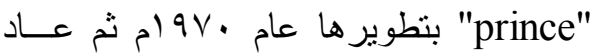
جوردون عام ا9Vام، وقام بمر اجعة هــذه الطريقة وتطوير ها (مجدي عزيز إبــر اهيم،

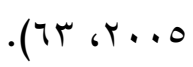

و الغرض منها إنتاج وتوليد الأفكـار

و الحلول الابتكاريــة للمـشكلات باســتخدام

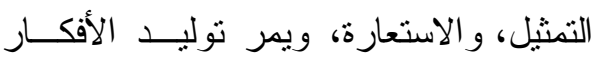

ب. معالجة المشكلة بما يعين على بلورتها

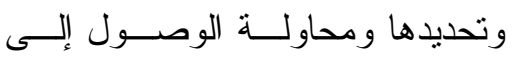
الحلول الملائمة لها.

ت. التقييم للأفكار التي تم التوصل إليهـــا.

و التي تمنل بدائل مختلفة للحل الملائم للمشكلة. r. السلوك الابتكاري له عائدة (ناتجه) الذي

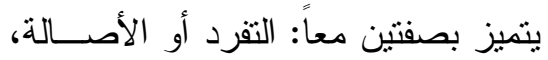
القيمة و الفائدة العلمية.

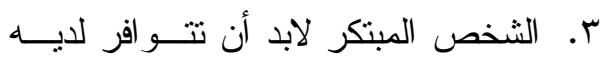

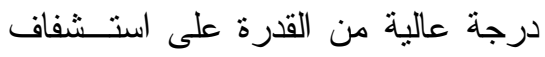
المشكلات. ع. أول ما يواجهنا في أي مشكلة هو أنــهـ

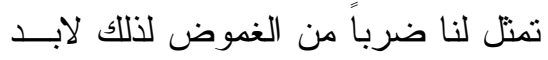
من تحديد المشكلة وبلورنها وتوضـيـح مختلف جو انبها (فادية عادل الخضر اء،

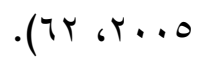
ويمكن تحديد الخطــــوات الو اجــب إنباعهــــا في أسلوب حل المشكلات الابتكــاري كمــــا يلي:

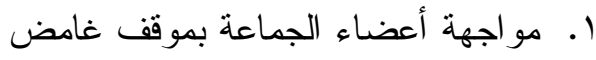
أو مشكلة محيرة.

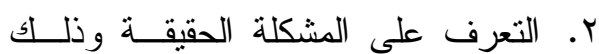
بالبحث عن الحقائق المرتبطة بالمـشكلة

$$
\text { وتحديدها. }
$$

r. وضع بدائل متعددة لحل المشكلة. 
البيو اخلاقية قائم على التعلم المُــنظم ذاتيـــاً دراسات سابقة وتتفيذ التعديل الأكاديمي ومهار ات التفكيــر

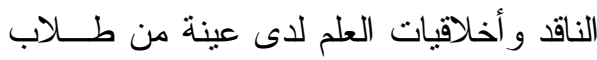

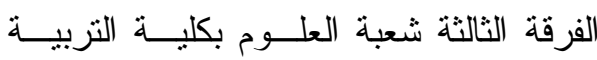

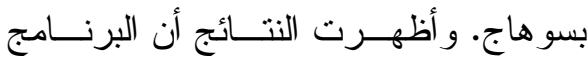

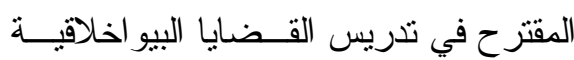

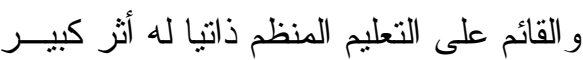
في التفكير الناقد ككل ومهار اته الخمسة (دقة الاستتناج-معرفة الافتر اضيات-الاستدلال -

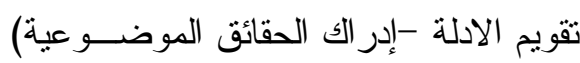
لدى طلاب مجمو عة البحث.

هــــت دراســة Nalcaci)

تحديد العلاقة بين القيم الثخصية ومهــارات التفكير النقدي للطــلاب المعلمــين للعلــوم الاجتماعية، وتكونت عينــة الدراســـة مــن (Y^) طالبا، في السنوات: الأولى، و الثانية،

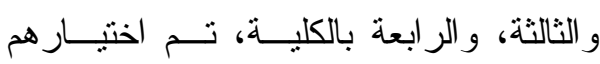
عشوائياً باستخدام طريقة العينات الطبقيـــة.

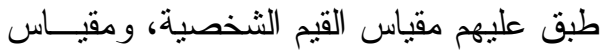
التفكير الناقد. وكان من بين اهم ما توصلت

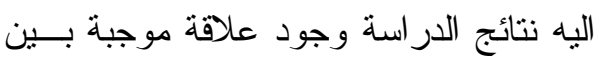
درجات القيم الثخصية و التقكير النقدي، و أن

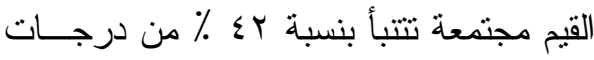

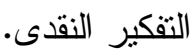

2016) Sahin; واستهدفت در اســة (Tunca, Altınkurt\& Y1lmaz

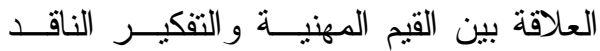
أولاً: تعرض الباحثة فيما يلى عـدداً مسـن الار اسات التي تناولت العلاقة بين القيم الأخلاقية و التفكير الناقد:

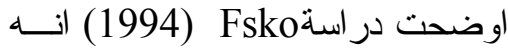
تم إجر اء الكثير من الدراسات حول التفكيــر الناقد و التفكير الأخلاقي، ولكن لم ينم إجر اء الكثير من الدراســات عـن العلاقــة بـين العين

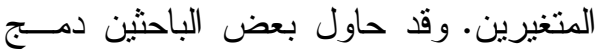

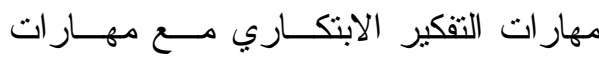

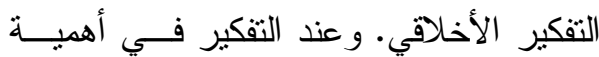

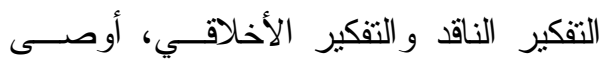

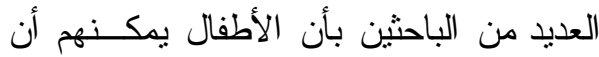

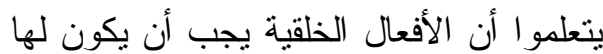

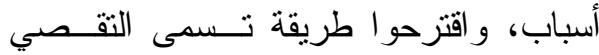

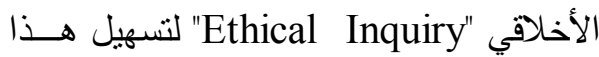
التعلم و العلاقة. وبشكل ما، نم الإشارة إلـى

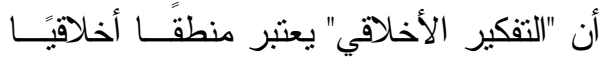

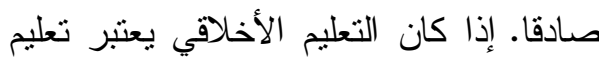

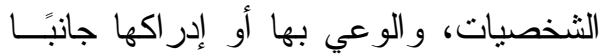

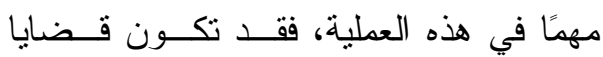
الثخصية أيضًا من مسائل الإدر الك. ويلاحظ الآثار المترنبة على ذلك في تصميم المناهج،

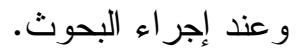
بينما اهتمت در اسة عاصــم محمــــ

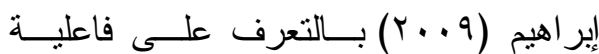

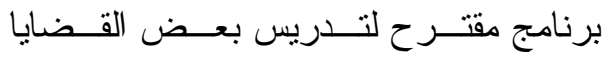




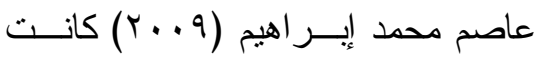
على طلاب المرحلة الجامعيــة، وفــى لهـ

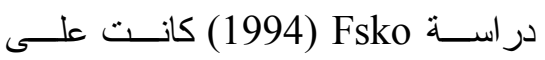

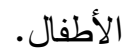

- أوضحت نتائج در اسة (عاصــم محمـــ

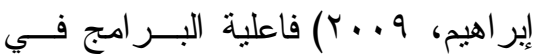
تتمية القيم الاخلاقية و التفكير الناقد . - اقترحت دراسة Fsko (1994) طريقة تسهى "التقصي الأخلاقي" لتسهيل تعلــيم الأفعال الأخلاقية.

ثانياً: تعرض الباحثة فيما يلى عـدداً مسن الدهن الدراسات التي تناولت العلاقة بين القيم الأخلاقية و التفكير الابتكاري.

هدفت در اسة فايزة محمد سعيد عبــــ

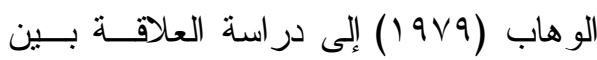

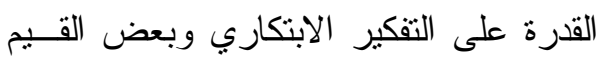

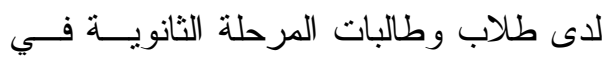
الجمهورية العر اقية. وقد بلغت عينة البحــث

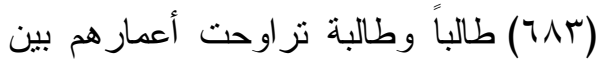
10-10 سنة طبق عليهم اختبار القدرة على التقكير الابتكاري (إعداد ســيد خيــر الله)، واختبار القيم (إعداد عطية هنا)، وكان مــن

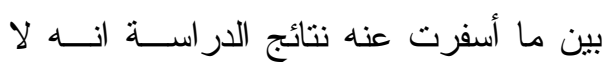
توجد علاقة ذات دلالة إحصائية بين الابتكار و القيم لدى عينتــي البحــث مــن الــذكور

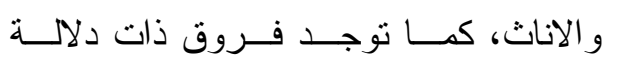

لمعلمي العلوم و التكنولوجيــا و الرياضـــيات

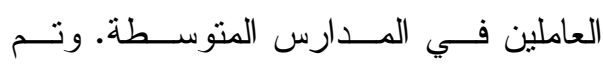

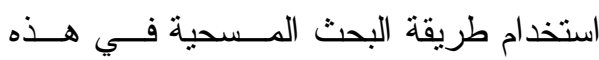

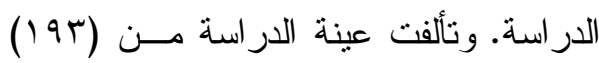

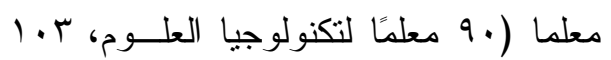
للرياضيات) يعملون في المدارس المتوسطة

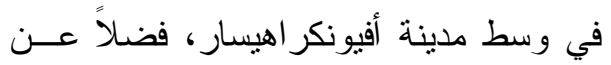
القرى في نفـس المقاطعــة خـــلال العــام

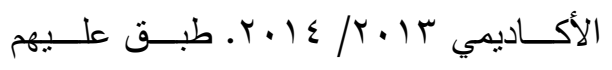
مقياس القـيم المهنيــة للمعلمـين (TPVS) ومقياس كاليفورنيا للتفكير الناقد (CCTDI)

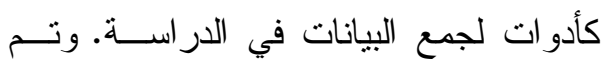

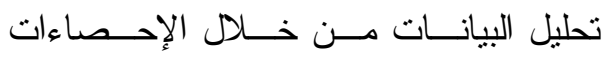
الوصفية، و اختبــار (ت)، وتحليـلـل التبــاين الأحادي ANOVA، ومعاملات الارتبــاط. وكان من بين اهم ما توصلت اليــه نتــائج الدر اسة هو أن مستوى المعلمين ذوي القـيم لهيم

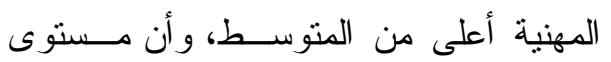

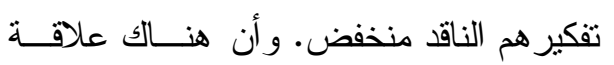

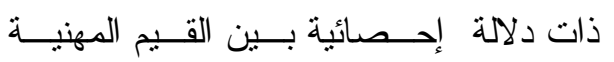
للمعلمين و الميل للتفكير الناقد. تعقيب: - أثنارت در اســة Fsko (1994) إلـى وجود علاقة موجبة بين القيم الأخلاقيـــة ومهار ات التقكير الناقد. - تتوعت المرحلة العمرية لعينة البحــث في الدر اسات السابقة فكانت فى در اســـة 
وتم تقييم التفكير الأخلاقي من خلال اثثتـين

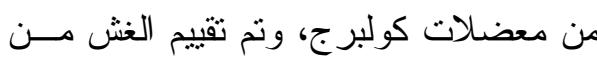

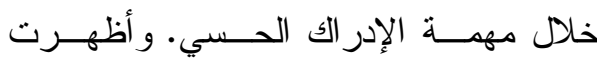

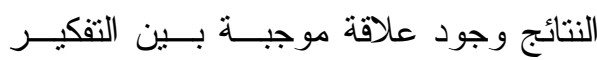
الأخلاقي ما بعد التقليدي وخيانـــة الأمانـــة. وفي الواقع، كلما اقترب التفكير الأخلاقي من بن

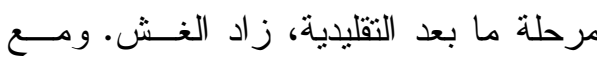
ذللك، لم يتم العثور على ارتباط كبيــر بــين الإبداع و الغش. وتكثثف هذه الدراسة عـنـ

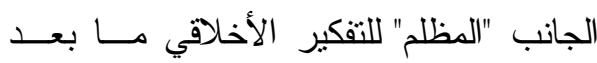
التقليدي، متحدية الاعتقاد السائد بأن الأخلاق تمنع الغش. تعقيب:

- توصلت نتائج در اسة دعاء ممدوح محمد (Y) (11) إلى وجود علاقة موجبة بـين القيم الأخلاقية و الابتكار ، ومن الدر اسات الأجنبية دراســة Antoniou (2015) الى وجود علاقة ضــعيفة بـين الغــش

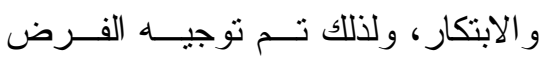

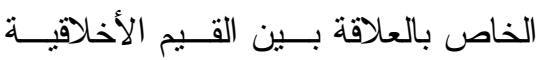
و التفكير الابتكاري في الدراسة الحالية. - اتفقت المرحلة العمرية لعينــة الدراســـة

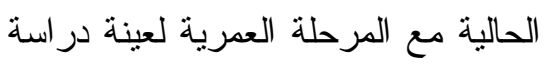
فايزة محمد سعيد عبد الوهاب (9V9 ( 9 )

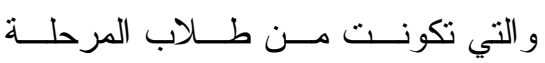

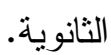

إحصائية في القيم الاجتماعية والدينية لصالح المرتفعين في الابتكار من الاناث.

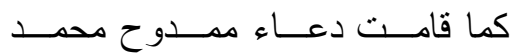

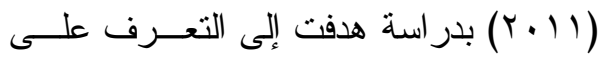

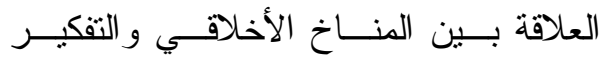

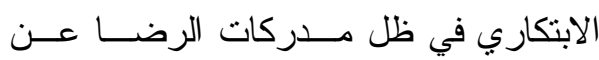

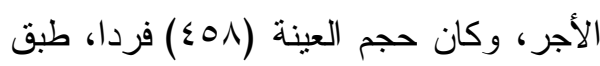

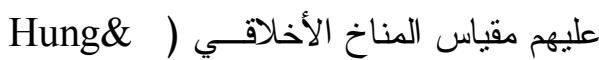
(tsai )، ومقياس (عبد الوهاب و عامر ، 99 (1) ) للتنكير الابتكاري، وكان من بين النتائج التي

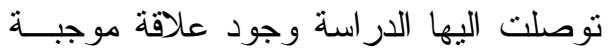

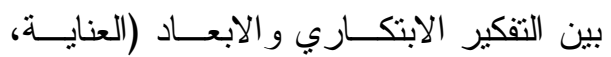
القانون و الدستور المهني، الوسائل) من ابعاد

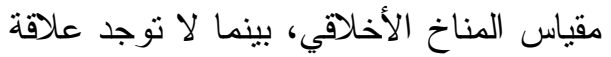
بين التفكير الابتكاري وبعــدي الاســنقلالية و القو اعد من ابعاد مقياس المناخ الأخلاقي. و واشـــــارت در اســـــة Antoniou 2015) إلى أن إحدى الدر اسات أثنتت علاقة

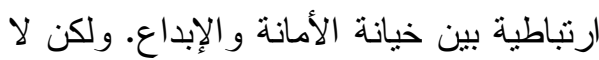
توجد در اسات تربط بين التفكير الابتكــاري لهاري

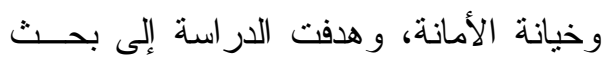

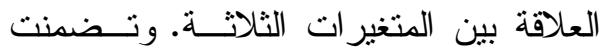
الدراسة الفروض: أن التفكير الأخلاقي مـــا بعد التقليدي يرتبط بصورة موجبة بكل مسن لـن

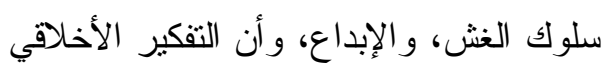

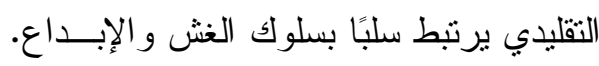

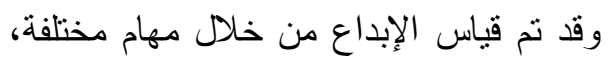




\section{إجرايات الدراسة: \\ أولا عينة الدراسة:}

تكونت عينة البحث من (VTr) طالباً

وطالبة بالصف الأول الثانوي للعام الدراسي لكن

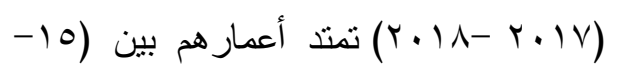

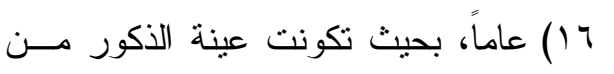

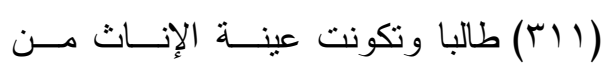

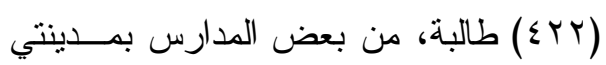

$$
\text { المنصورة و السنبلاوين }
$$

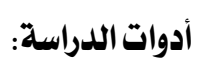

•. مقياس القيم الأخلاقية (إعداد: الباحثة)

•. اختبار كاليفورنيا لمهارات التفكير الناقد

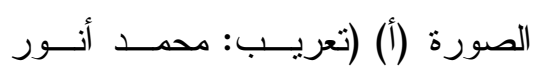

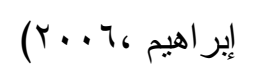

•. اختبار التفكير الابتكاري (ممدوح عبــــ

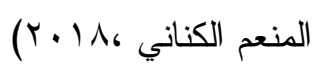

( •)مقياس القيم الأخلاقية:(اعداد:الباحثــة

(الحالية)

تم تحديد القيم الأخلاقية موضع البحث

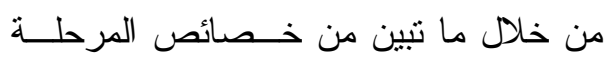

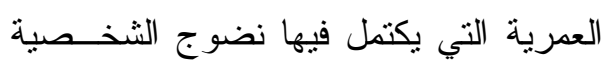

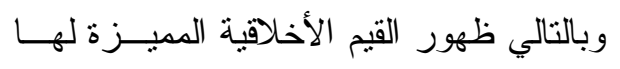

عن غيرها، و الني تضـح مــن خــلال ردود

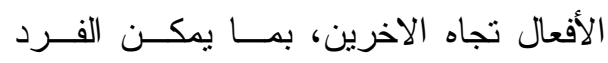

من القدرة على حل مشكلاته و اتخاذ قرار اته الهاه

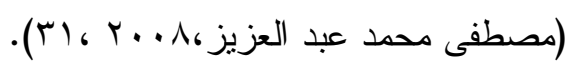

- استخدمت فايزة محمد سعيد عبد الوهاب

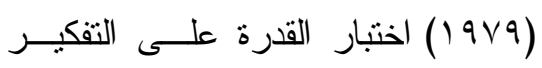

الابتكاري (إعداد سيد خير الله).

- تشير نتائج در اسة فايزة محمد سعيد عبد

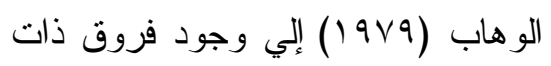

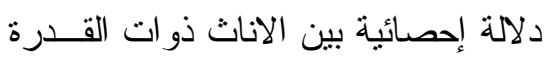

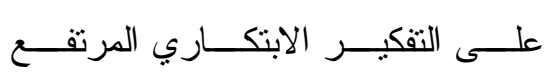

و المنخفض في القيم لصالح الاناث ذوات الابن

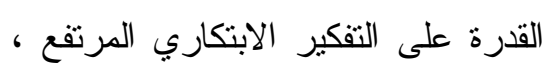

و عدم وجود علاقة ذات دلالة إحــصائية

بين الابتكار و القيم لدى الذكور و والاناث دلث دلاث

، كما توجد فروق ذات دلالة إحــصائية

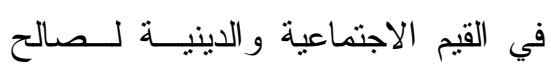

الاناث ذوات التفكير الابتكاري المرتفع

، بينما توجد فروق ذات دلالة إحصائية

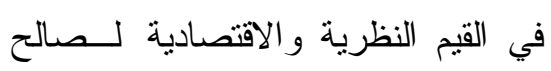

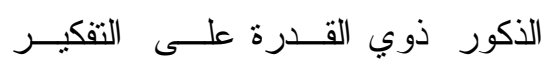

$$
\text { الابتكاري المرتفع • }
$$

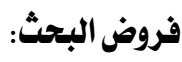

في ضوء الإطار النظري و الدراسات السابقة يمكن صياغة الفروض الآتية:

• - يوجد ارنباط موجب دال إحصائيا بين

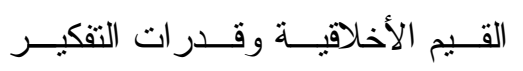

$$
\text { الابتكاري. }
$$

• - يوجد ارتباط موجب دال إحصائيا بين

القيم الأخلاقيــة ومهـــار ات التفكيــر 
من المتخصصين في علم الــنفس التربــوي

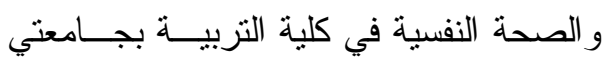

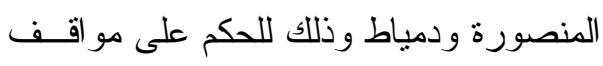
المقياس من حيث مدى مناسبة القيم لأهداف المقياس ومدى انتماء مو اقف كل قيمة للقيمة

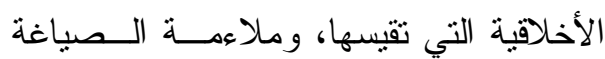

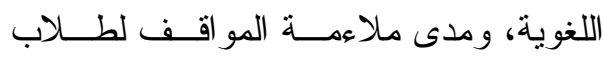
الصف الأول الثانوي، بالإضافة إلى تعـديل

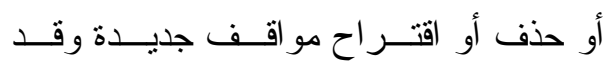
تر اوحت نسب الاتفاق على مفردات المقياس

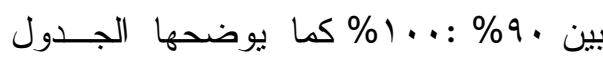
التالي:

الاتساق الاخلي لمقياس القيم الأخلاقية: تم حساب معاملات الارتباط باستخدام معامل ارتباط بيرسون بين درجة كل موقف بالدرجة الكلية للقيمة التي نتنمي إليها، فـي دئي

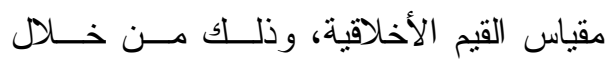
تطبيق المقياس على عينة مكونة من (10.) طالباً وطالبة بالصف الأول الثانوي، وجاءت علئ هن

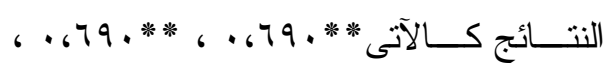

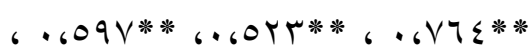

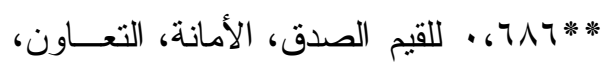

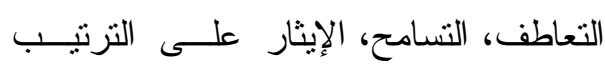

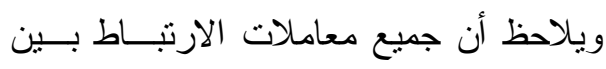

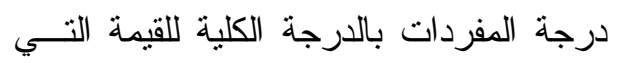

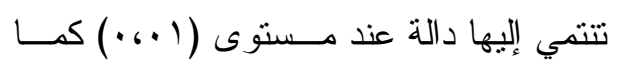

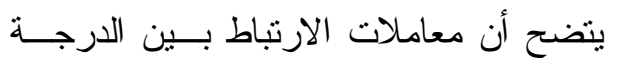

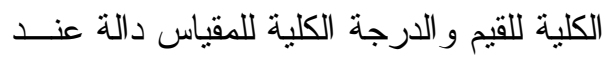

واطلعت الباحثنـة علــى الأدبيــات

العربية و الأجنبية و عدد من المقاييس المتعلقة

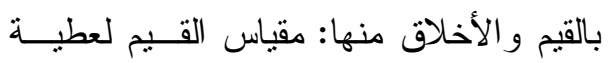

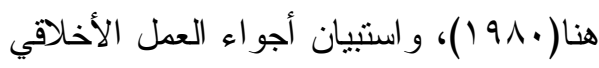
لفيكتور وجيلين (Fictor \&Jilin,1988)،

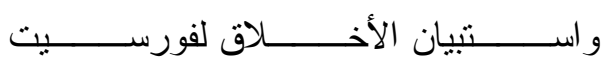
(Foerst,1980)، ومقياس النسق الأخلاقي

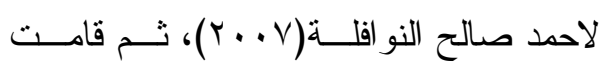

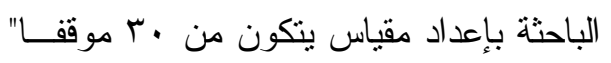
بحيث يكون خمسة مواقف لكل قيمة أخلاقية

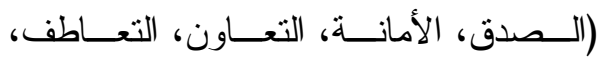
التسامح، الإيثار) ويتم تقدير الدرجة على كل الأن

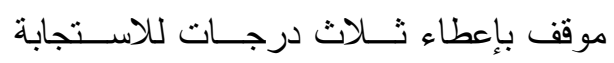

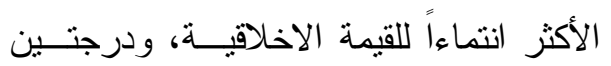

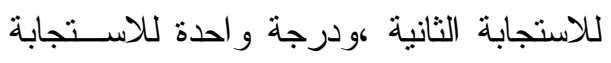
الثالثة الأقل انتماءاً للقيمة الأخلاقية. الخصائص الـسيكومترية لمقيــاس القـيم الأخلاقية:

قامت الباحثة بــالتحقق مـن صــدق وثبات مقياس القيم الأخلاقية كما يلي:

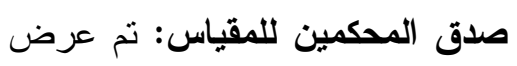

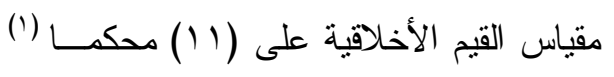

(1) و أتوجه بالثكر للسادة المحكمين على مجهوداتهم ألها

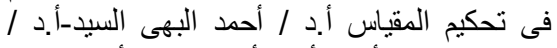

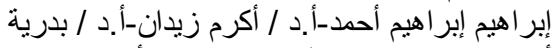

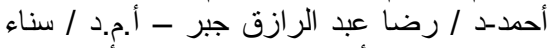

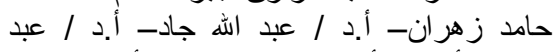

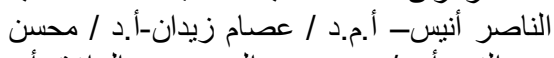

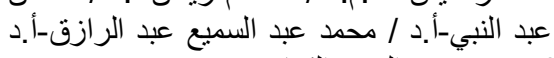

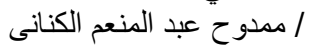




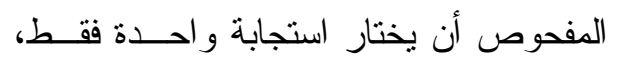
ويتحدد نقدير الدرجة على كل موقف بإعطاء

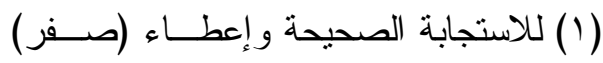
للاستجابة الخطأ.

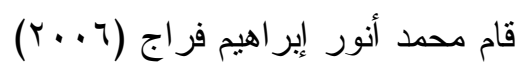

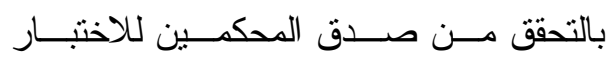
بعرض الاختبار على مجموعة من المحكمين

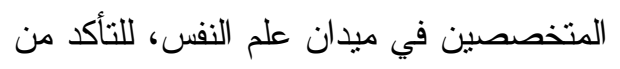

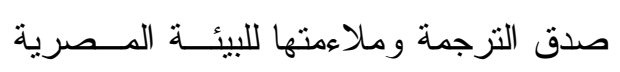
و العربية، ومن وضوح تعليمـات الاختبــار

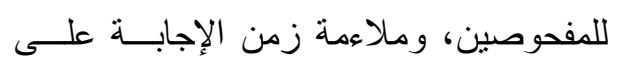
الاختبار أيضا، وبلغت نسبة اتفاق المحكمين

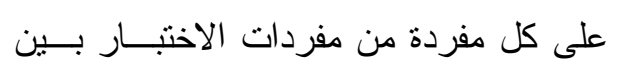

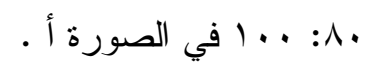

كما قام محمد أنور إبـــر اهيم فـــــاج

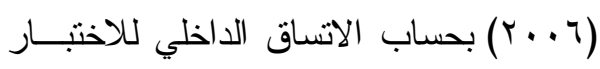

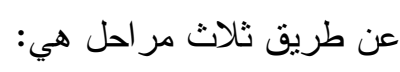

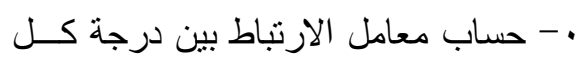

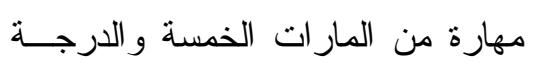

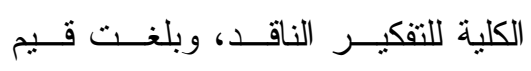

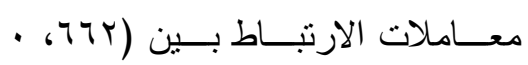

$$
\text { ، ،101، ، · ) في الصورة (أ). }
$$

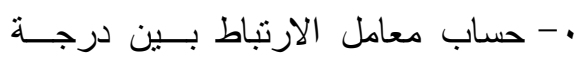

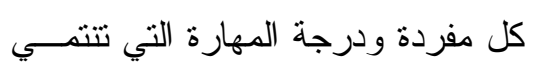

$$
\text { اليها. }
$$

ب- حساب معامل الارتباط بين درجة كــلـ مفردة و الدرجة الكلية علــى اختبـــار

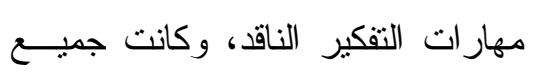

مستوى (l •،•)، (صــلاح مــر اد، أمــين

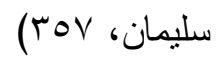
ثبات مقياس القيم الأخلاقية: نم حساب ثنات مقياس القيم الأخلاقية

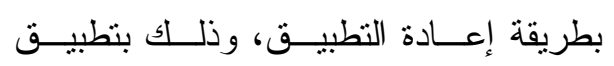

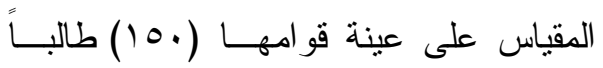

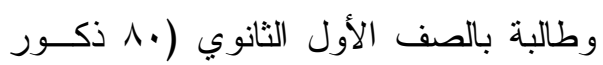

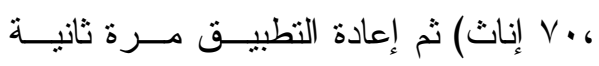
بفاصل زمني أسبوعين، وجاءت قيم إعاد معامل

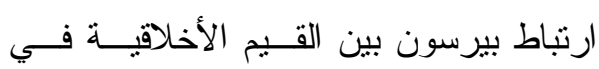

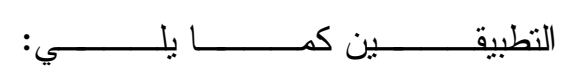

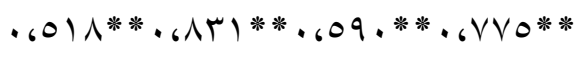

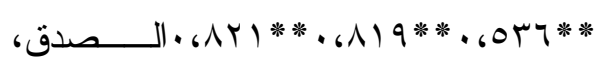

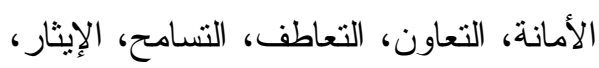
الدرجة الكلية على الترتيب.

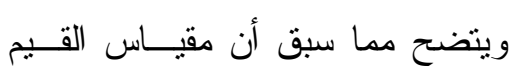

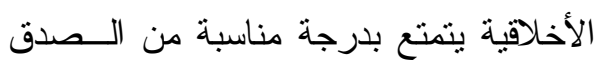

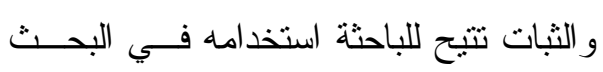
الحالي. (Y) اختبار كاليفورنيا لمهــارات التفكيــر

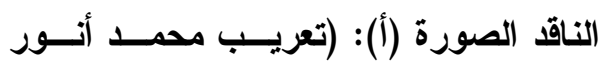

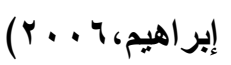
يتكون اختبار كاليفورنيــا لمهــار ات

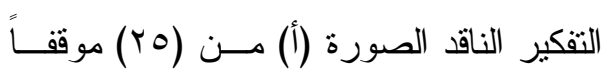

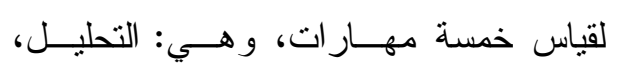

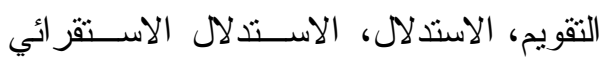

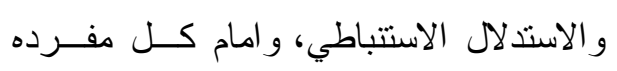

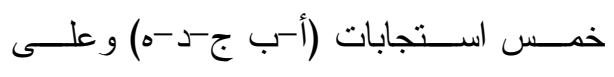




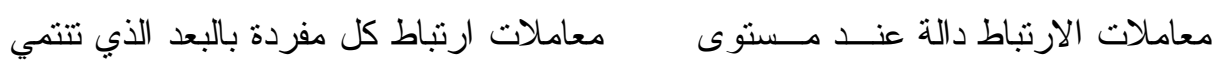

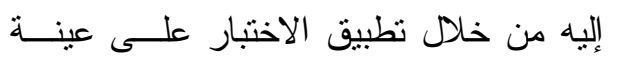

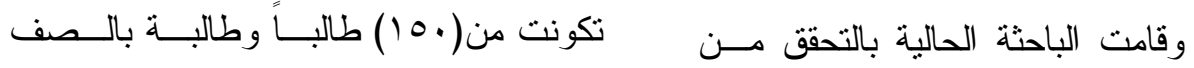

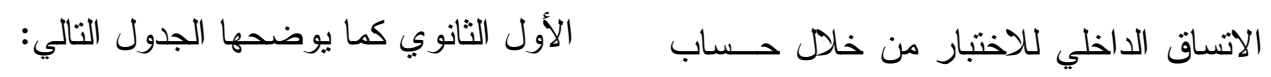

(1) جدول

قيم معاملات ارتباط بيرسون بين درجة كل مفردة بالارجة الكلية للبعد

الأي تتنمي إليه في اختبار التفكير الناقد.

\begin{tabular}{|c|c|c|c|c|c|c|c|c|c|}
\hline \multicolumn{2}{|c|}{ مهارة الاستدلال } & \multicolumn{2}{|c|}{ مهارة الاستدلال } & \multicolumn{2}{|c|}{ مهارة 1 الاستدلال } & \multicolumn{2}{|c|}{ مهارة التقويم } & \multicolumn{2}{|c|}{ مهارة التحليل } \\
\hline معامل & رقم & معامل & رقم & معامل & رقم & معامل & رقم & معامل & رقم \\
\hline الارتباط & المفردة & الارتباط & المفردة & الارتباط & المفردة & الارتباط & المفردة & الارتباط & المفردة \\
\hline . $60 \wedge \Gamma^{*} *$ & r) & $.60 . V^{*} *$ & 17 & . & 11 & . $، \sum V Y^{*} * *$ & 7 & . $67 / 7 \% *$ & 1 \\
\hline & rt & . ‘ $\ \neg . * * \%$ & iv & • ،乞ケ人*** & ir & $\cdot 0 \leq \leqslant * *$ & v & $.60 \wedge \% * \%$ & r \\
\hline . ، $\{\curlyvee 人 * *$ & rt & ש & 11 & $.00 .1 \% *$ & r & . 6 TYO** & $\wedge$ & . $\mathrm{TVO}$ \%* & $r$ \\
\hline " & $r \varepsilon$ & . $\preccurlyeq\{Y * *$ & 19 & . ، $\{.0 * *$ & $1 \varepsilon$ & . $५ 99 * *$ & 9 & $.0 \leq \leqslant \% *$ & $\varepsilon$ \\
\hline . $ヶ \vee \vee 9 * *$ & ro & . $\measuredangle \& Y Y * *$ & r. & . ، $\leqslant$ ४ \%** & 10 & $.60 \wedge 1 * *$ & 1. & . $イ 70 \% *$ & 0 \\
\hline
\end{tabular}

** دالة عند مستوى ال.,.

\begin{tabular}{|c|c|}
\hline. $.071 * *$ & التحليل \\
\hline $.600 . * *$ & التقويم \\
\hline $.6 \Upsilon 9 人 * *$ & الاستدلال \\
\hline . & الاستدلال الاستقر ائي \\
\hline. $.0 \mathrm{VV} * *$ & الاستدلال الاستتباطي \\
\hline
\end{tabular}

كما تم حساب معاملات الارتباط بين

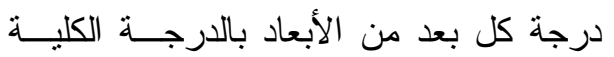

للاختبار وجاءت النتائج كما يوضحها جدول الاعال بلان

جدول (r)

قيم معاملات ارتباط بيرسون بين درجة كل

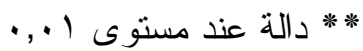

بعد بالارجة الكلية لاختبار كاليفورنيا

يتضح من نتائج الجــدولين (Y، (Y) أن

لمهارات التفكير الناقد

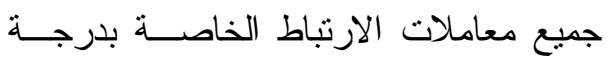

\begin{tabular}{|c|c|}
\hline معامل الارتباط & مهار ات التفكير الناقد \\
\hline
\end{tabular}


جلول (r)

قيم معاملات ثبات ألفا كرونباخ لأبعاد اختبار كاليفورنيا لمهارات التفكير الناقد و الارجة الكلية

\begin{tabular}{|c|c|}
\hline معامل الثبات & مهارات التفكير \\
\hline $.670 \% * *$ & التحليل \\
\hline . 6 Tイ & التقويم \\
\hline . $67 \leqslant$ \%*** & الاستدلال \\
\hline $.0 \mathrm{VYr} * *$ & الاستدلال الاستقرائي \\
\hline $.004 \% *$ & الاستدلال الاستنباطي \\
\hline $.0001 \% *$ & الارجة الكلية \\
\hline
\end{tabular}

يتضح من جدول (^) أن قيم معاملات

ثبات ألفا كرونباخ لأبعاد اختبار كاليفورنيــا

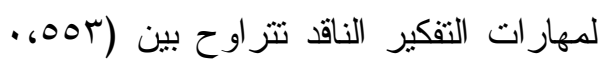

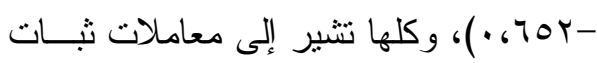
مقبولة.

ومما ســبق يتــضح تمتــع اختبـار

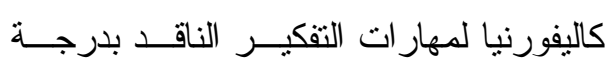

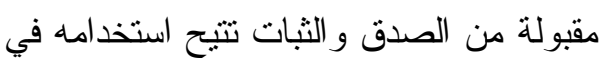
البحث الحالي. (ب) اختبار التفكيـر الابتكــاري:(اعـــاد:

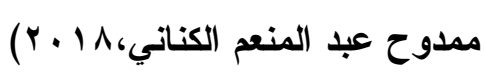
أعد هذا الاختبار مددوح عبد المــنعم الكناني، ويقيس القدرة على التفكير الابتكاري من خلال ثلاثة ابعاد هي (الطلاقة، المرونة،

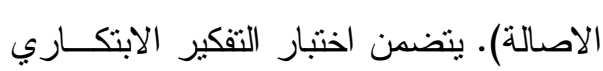

المفردة و البعد الذي تتنمي إليـــه و الخاصــة

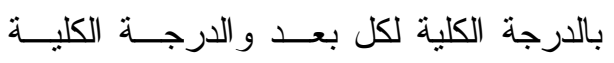
لاختبار كاليفورنيا لمهار ات التقكير الناقد دالة عند مستوى (..... ثبات الاختبار:

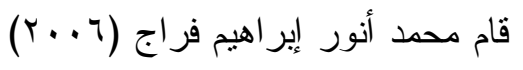

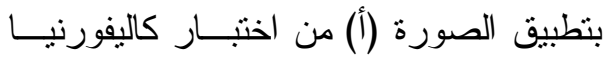
لمهارات التفكير الناقد على عينة استطلاعية

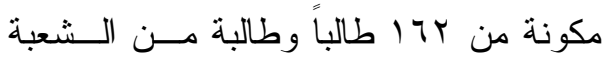

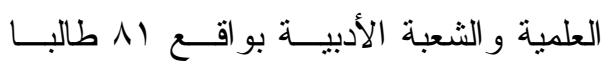
وطالبة لكل من الــشعبة العلميــة والـشـعبة الأدبية من الفرقة الثالثة بكلية التربية جامعة

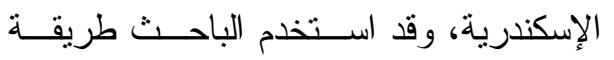

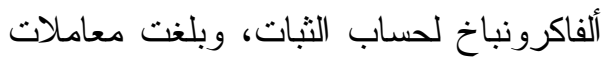
الثبات للاختبار وللمحاور الخمسة لاختبــار

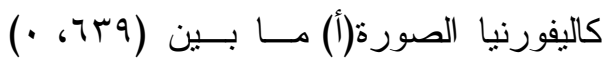
و (799، · · ) وهي معاملات ثنات مناسبة مما يؤكد موثوقية الاختبار . كما قامــت الباحثــة بــالتحقق مــن

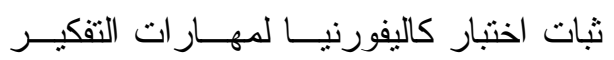
الناقد (الصورة أ) عن طريق معامــل ألفــــا

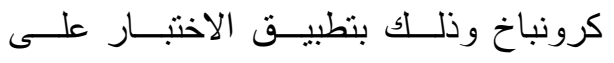

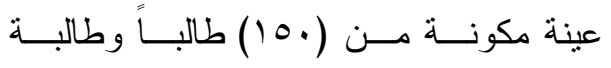

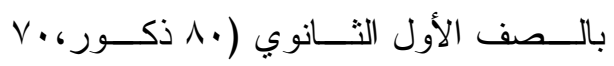
اناث)، وجاءت النتائج كما يوضحها الجدول

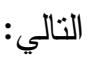


بتطبيق الاختبار على عينـــة مكونـــة مــن

(Y. (Y) من طلاب الفرقة الثالثة بكلية التربية

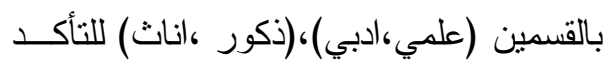

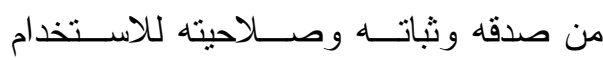
و التطبيق، ويتت حسـساب الثبــات للاختبــار

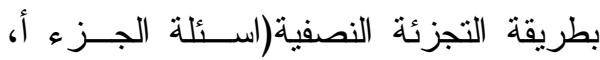
اسئلة الجزء ب) فبلــنغ (بو، ، · ) للاختبــار

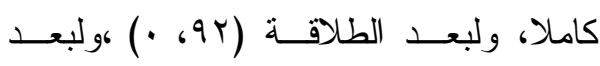

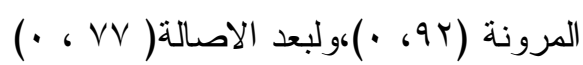

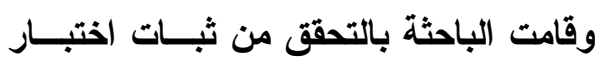
التفكير الابتكاري بطريقتين:

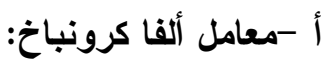

تم حســاب ثبــات اختبـــار التفكيــر الابتكاري للأبعاد و الارجة الكليــة للاختبـــار عن طريق معامل ألفا كرونباخ وذلك بتطبيق

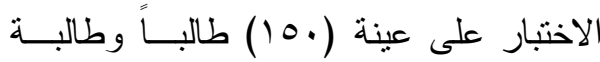

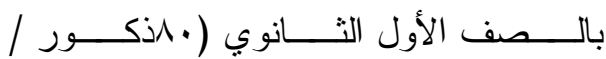

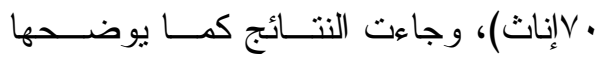

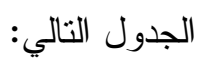

جدول (؟)

قيم معاملات ثبات ألفا كرونباخ لأبعاد اختبار

\begin{tabular}{|c|c|}
\hline \multicolumn{2}{|c|}{ لجبتكاري و الالا } \\
\hline معامل الثبات & قدرات التفكير الابتكاري \\
\hline . (V) O*** & الطلاقة \\
\hline . $V \leqslant$ V *** & المرونة \\
\hline . $\vee$ V07*** & الأصالة \\
\hline . & الدرجة الكلية \\
\hline
\end{tabular}

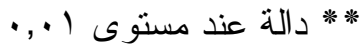

ثمانية فقرات موزعة على أربعة أسئلة وكل سؤال مكون من فقرتين (أ، ب)، وزمن كل سؤ ال خمس دقائق. وتحسب درجة المفحوص علـى الاختبـار كالتالي: 1 - الطلاقة: يعطى المفحوص درجة و احدة لكل استجابة مناسبة.

Y - المرونة: يعطى المفحوص درجة و احدة

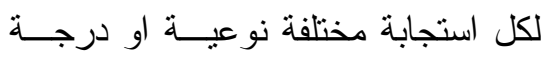
واحده على كل مجموعة استجابات تدور كلها حول فكرة واحدة.

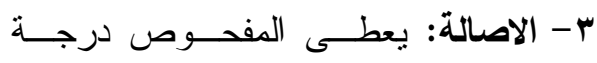

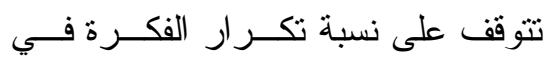

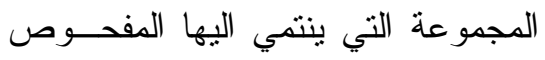
كالتالي: أ-ه درجات إذا تكــررت بنــسبة اقــل .(\%).)

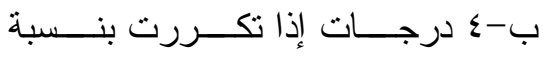

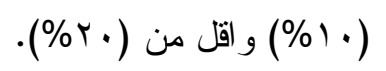
ج-r درجات إذا تكررت بنسبة (·r\%) و اقل من (•r\%).

د- درجتان إذا تكررت بنـــبة (•r\%) و اقل من (• ^؛\%). ه- درجة واحــدة إذا تكــررت بنـسبة

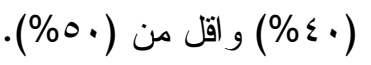

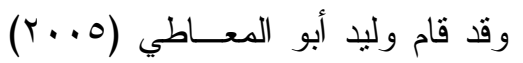


ويتضح من نتائج جدول (0) أن قـيم

يتضح من جدول (ع ) أن قيم معاملات

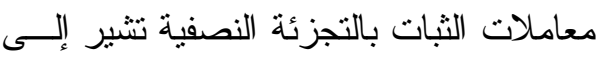

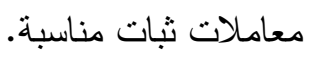

ومما سبق يتضح تمتع اختبار التفكير

الابتكاري بدرجة مقبولة من الصدق و الثبات

$$
\begin{aligned}
& \text { تتيح استخدامه في البحث الحالي. } \\
& \text { نتائج فروض البحث: } \\
& \text { الفرض الاول: }
\end{aligned}
$$

ينص على أنه: " يوجد ارنباط موجب

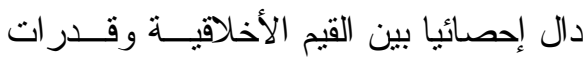

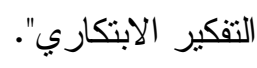

و لاختبار الفرض الاول قامت الباحثة

بحساب معامل ارتباط بيرسون بين درجـات

الطلاب في القيم الأخلاقية ودرجاتهم في كل من التفكير الابتكاري وذللك لعينـــة الــذكور

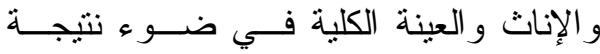

الفرض الأول، وجاءت النتائج كما بالجــــول ضول

$:(7)$
ثبات ألفا كرونباخ لأبعاد التفكير الابتكــاري

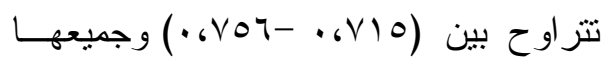
تشير إلى معاملات ثبات مقبولة.

ب -طريقة التجزئة النصفية:

تم حساب ثبات درجات اختبار التفكير

الابتكاري باستخدام طريقة التجزئة النــصفية

لمفــردات الاختبــار وتــصحيح معـاملات

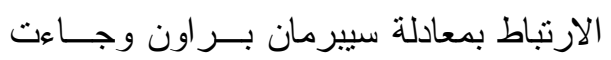

\begin{tabular}{|c|c|c|}
\hline \multicolumn{3}{|c|}{ التفكير الابتكاري } \\
\hline معامل الثبات & معامل الارتباط & قار ات التفكير \\
\hline . ،A11 & 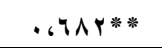 & الطلاقة \\
\hline . הNY &.,$v \cdot r * \mu *$ & المرونة \\
\hline .6901 & . $69.7 * \% *$ & الأصالة \\
\hline .6901 & . .919\%** & اللارجة الكلية \\
\hline
\end{tabular}

النتائج كما يوضحها جدول (0):

جذول (•)

معاملات الثبات باستخدام التجزئة

النصفية (طريقة سييرمان براون) لاختبار

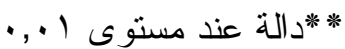


جدول (†) معاملات ارتباط القيم الأخلاثية بقدرات التفكير الابتكاري

\begin{tabular}{|c|c|c|c|c|c|c|c|c|c|}
\hline \multicolumn{7}{|c|}{ القيم الأخلاقية } & \multirow{2}{*}{ العينة } & \multirow{2}{*}{ الأبعاد } & \multirow{2}{*}{ المتغير } \\
\hline الارجة الكلية & الإيثار & التسامح & التعاطف & التعاون & الأمانة & الصدق & & & \\
\hline זד •,. &., $9 \vee 0$ & $\cdot, \cdot r \varepsilon$ & $\cdot,, \quad \leq 7$ & r., or & ., . & •, & العينة الكلية & الطلاقة & \multirow{8}{*}{ التفكير الابتكاري } \\
\hline$\cdot, \cdot r V$ & $\cdot, \cdot \Delta r-$ & $\cdot, \cdot 1 \mathrm{~V}$ & ror & $\cdot, \cdot r q$ & $\cdot, 1 \cdot r$ & $\cdot, \ldots 0-$ & ذكور & \multirow{3}{*}{ المرونة } & \\
\hline$\cdot, \cdot \wedge 1$ & $\cdot, \cdot T \varepsilon$ & $\cdot, \cdot r \varepsilon$ &., .19 & $\cdot, .91$ &., $.97 *$ &., $.0 \leqslant$ & إناث & & \\
\hline$\cdot, \cdot T V$ & ., &., .10 & 政 & X &., $1 Y \Lambda^{* * *}$ & V & الكلية & & \\
\hline$\cdot, \cdot \leq q$ & $\cdot, \cdot, 1 \leqslant-$ &.,$\cdot{ }^{\prime}$ & $\cdot, \cdot \pi r$ & $\cdot, .19$ & $\cdot, \cdot \leq V$ & $\cdot, \cdot r q$ & ذكور & \multirow{3}{*}{ الأصالة } & \\
\hline$\cdot, \cdot r$ & $\cdot, \ldots r$ & $\cdot, \cdot, \leqslant \leqslant$ & $\cdot, \cdot r-$ & $\cdot, \cdot V r$ & $\cdot, \ldots$ & $\cdot, \cdots \wedge$ & إناث & & \\
\hline., ro & $\cdot, \cdot r$ & $\cdot, \cdot \leq r$ & $\cdot, \ldots v-$ & $\cdot, \cdots 7$ & $\cdot, \cdot 1-$ & $\cdot, \cdot Y \wedge$ & الكلية & & \\
\hline זד •,. & $\cdot, \ldots 1$ & $\cdot, \cdot r \varepsilon$ & $\cdot, \cdot \leq 7$ & .,. Or & ., $1 q^{* * *}$ & $\cdot, \cdot r q$ & الكينة & الالكلية & \\
\hline
\end{tabular}

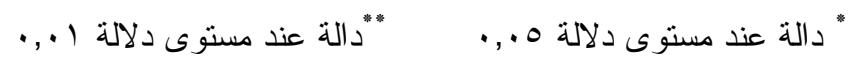

يتضح من جدول (†) ما يلي:

- لا يوجد ارتباط دال إحصائياً بين القـيم

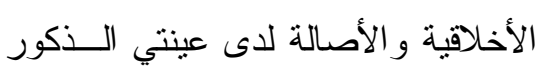

$$
\text { و الإناث وكذلك العينة الكلية. }
$$

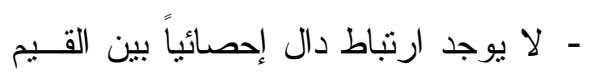

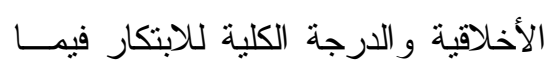

عدا الارتباط بين الأمانة والدرجة الكلية

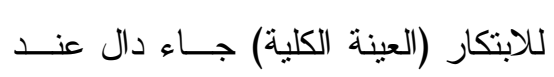

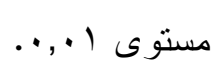

تفسير نتائج الفرض الاول:

تشير نتائج جدول(؟) إلى أن جميـع

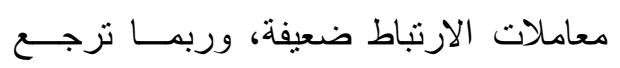

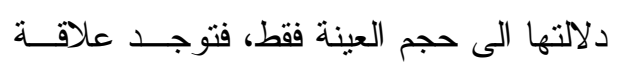

موجبة بين الارجة الكلية للقـيم الاخلاقيــة

و الطلاقة.
- يوجد ارتباط دال إحصائياً بين الأمانــة

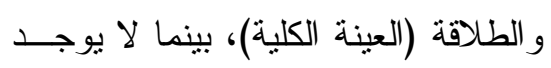

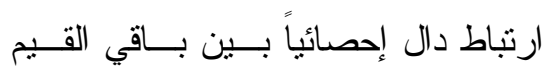

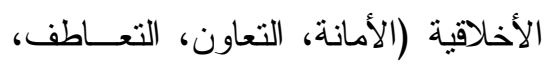

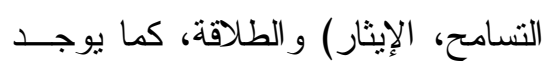

ارتباط دال إحصائيًاً بين الدرجة الكليــة الإنئة

للقيم الأخلاقية و الطلاقة.

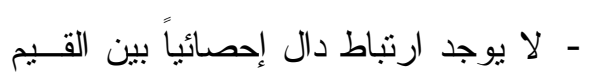

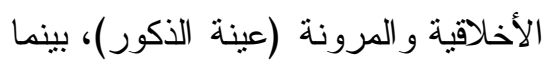

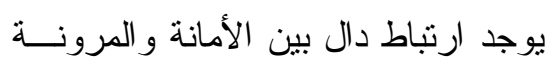

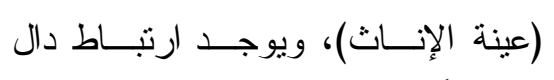

إحصائياً بين التعاون و المرونة (العينــة وئة

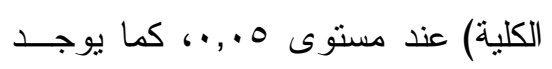

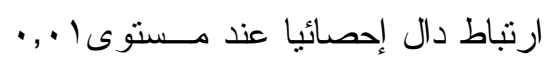

بين الأمانة و المرونة (العينة الكلية). 
ذواتهم، وهو مالا يتماشى مع القيم عمومســا

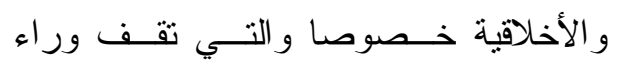
السلوك وتوجهه وتضبطه.

$$
\text { الفرض الثاني: - (الثئ }
$$

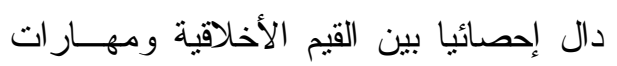

$$
\text { التقكير الناقد ". }
$$

ولاختبار الفرض الثاني قامت الباحثة

بحساب معامل ارتباط بيرسون بين درجـات

الطلاب في القيم الأخلاقية ودرجاتهم في كل من التفكير الناقد وذلك لعينة الذكور و الإناث و العينة الكلية في ضوء نتيجة الفرض الثاني،

$$
\text { وجاءت النتائج كما بالجدول (V): }
$$

ينص على أنه: "يوجد ارتباط موجب

$$
\begin{aligned}
& \text { وتتفق هذه النتيجة مع در اســـة ناديــة }
\end{aligned}
$$

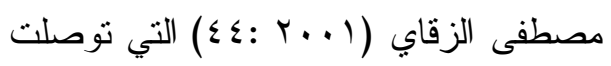

$$
\begin{aligned}
& \text { الى وجود علاقة ضعيفة وغير دالـــة بـين } \\
& \text { القدرة الابتكارية و القيم بمجالاتها الستة. } \\
& \text { وتختلف هذه النتيجــة مـــع در اســـة }
\end{aligned}
$$

(Beaussart; Andrews\& Kaufman, 2013: 2; Baas ; De Dreu \& نتأحس Nijstad, 2008: 803) نتائجها إلى أنه نوجد علاقة سالبة بين الأمانة و التفكير الابتكاري.

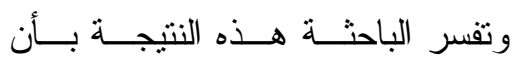

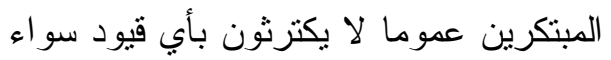

\begin{tabular}{|c|c|c|c|c|c|c|c|c|c|}
\hline \multicolumn{7}{|c|}{ القيم الأخلاقية } & \multirow[b]{2}{*}{ العينة } & \multirow[b]{2}{*}{ الأبعاد } & \multirow[b]{2}{*}{ المتغير } \\
\hline الارجية & الإيثار & التسامح & التعاطف & التعاون & الأمانة & الصدق & & & \\
\hline$\cdot, .911-$ & זד., & $\cdot, \cdot$ rA- & $\cdot, 111-{ }^{*}$ & $\cdot, \cdot \vee \vee \wedge-$ & $\cdot, 1 \vee \leqslant-$ & $\cdot, \cdot, \vee \wedge-$ & ذكور & \multirow{3}{*}{ التحليل } & \multirow{8}{*}{ التفاقير } \\
\hline$\cdot, .11$ & זr., & $\cdot, \cdot 10-$ & דצ', & $\cdot, \cdot$ YOO- & $\cdot, \cdot \varepsilon-$ & .,.0r & إناث & & \\
\hline$\cdot, \cdot \leq \leqslant \leq-$ & $\cdot, .71$ & $\cdot, \cdot 11-$ & $\cdot, .09-$ & $\cdot, \cdots \wedge-$ &., $1 \times q^{* *}$ & $\cdot, \cdot 1-$ & الكلية & & \\
\hline$\cdot, \cdot 1-$ &.,+ TV & $\cdot, \cdot Y I$ & $\cdot, \cdot Y r_{-}$ & $\cdot, \cdot Y Y_{-}$ &., $.0 \mathrm{~V}-$ & .,.,7r- & العينة الكلية & التقويم & \\
\hline$\cdot, \ldots r-$ & $\cdot, .0$ &., 19 & $\cdot, \cdot 1 \leqslant-$ & $\cdot, \cdot 1 Y-$ &., $.70-$ & $\cdot, \cdot$, ro- & العينة الكلية & الاستدلال & \\
\hline$\cdot, \cdots 7$ & $\cdot, \cdot, \leqslant 7$ & ס ., & $\cdot, \cdot 1 Y-$ & $\cdot, \ldots \circ-$ & $\cdot, .0 r-$ & $\cdot, \cdot, Y)-$ & العينة الكلية & الاستثترائلي & \\
\hline$\cdot, \cdots r$ & $\cdot, \cdot, 1 \leqslant$ & $\cdot, I V$ & $\cdot, \cdot 1 \leq$ & $\cdot, \cdot r$ & $\cdot, .0-$ & $\cdot, \cdot r V-$ & العينة الكلية & الاستتباطي & \\
\hline$\cdot, \ldots r-$ &., or & $\cdot, \cdot r \leq$ & $\cdot, ., 9-$ & $\cdot, \cdot 1 r-$ & .,. .77- & •, , + & العينة الكلية & الارجة الكلية & \\
\hline
\end{tabular}

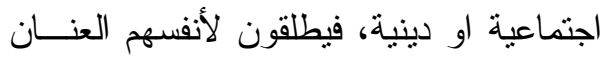

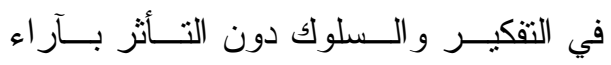
الاخرين او باي ضغوط اجتماعية، منطلقين،

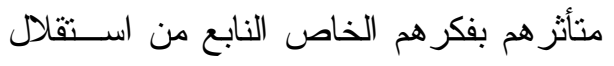

جدول (V) قيم ودلالة معاملات ارتباط القيم الأخلاقية ومهارات التفكير الناقد

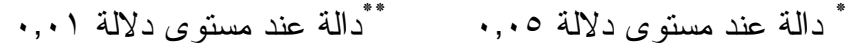




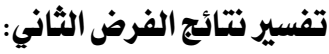

تشير نتائج جدول (V) إلى أن جميـع

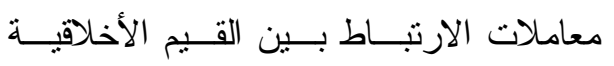
ومهار ات التفكير الناقد ضعيفة، وربما ترجع دلالتها لحجم العينة فقط.

Nalcaci تتفق هذه النتيجة مع در اسة (2012: 27 28) علاقة موجبة بين درجات القـيم الثخــصية و التقكير الناقد، وأن القيم مجتمعة تتتبأ بنسبة

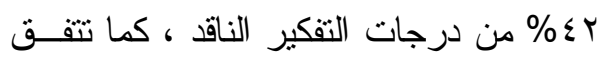

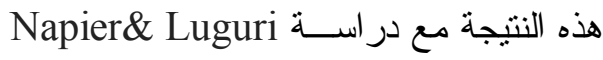
756 : 72013$)$ (التي توصلت الى ان التفكير

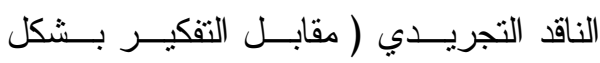
محسوس) برنبط بالقيم الأخلاقية ذات الطابع

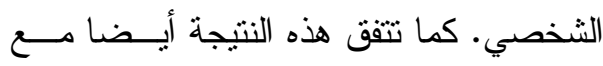
(2016: 30- 32) Sahin; Tunca, دراسة Altınkurt\& Y1lmaz وجود علاقة ذات دلالة إحصائية بين القـيم المهنية للمعلمين و الميل للتفكير الناقد. وتتفق هذه النتيجه مع ما أنثار اليـــ (2009: 339) Elkatmıs

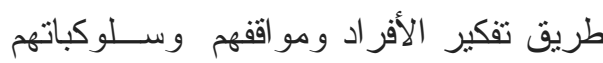

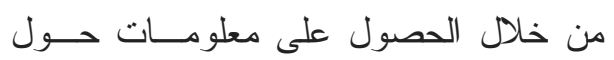
ونتير دراسة Ünal;

\section{يتضح من جدول (V) ما يلي:}

- لا يوجد ارتباط دال إحصائياً بين القـيم

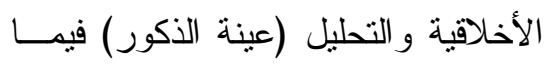

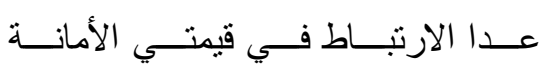

و التعاطف قد جاء دال عند مستوى دالة

ه., •، كما لا يوجد ارتباط دال إحصائياً

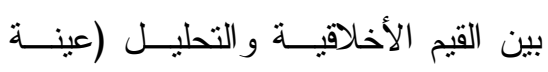

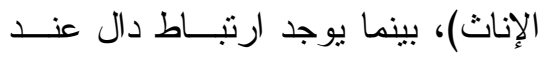

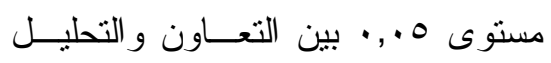

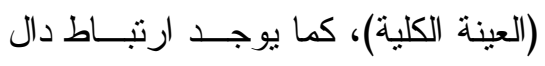

عند مستوى ا +,. • بين الأمانة و التحليل

(العينة الكلية).

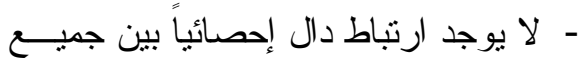

القيم الأخلاقية و التقويم (العينة الكلية).

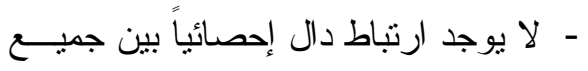

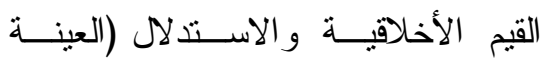

(الكلية).

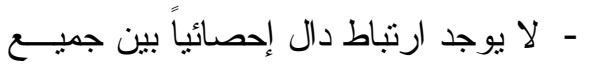
القيم الأخلاقية والاستدلال الاســتقر ائي (العينة الكلية).

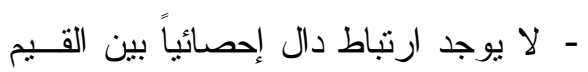
الأخلاقية والاستدلال الاستنباطي (العينة

(الكلية).

- ل لا يوجد ارنباط دال إحصائياً بين القـيم الأخلاقية و الدرجة الكلية للناقد (العينــة

(الكلية). 
•. . حث المعلمين على الابتعاد عن الأساليب

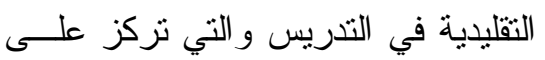

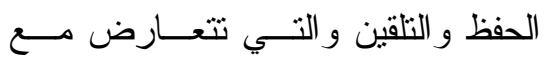
أساليب التفكير العليا (التفكير الابتكاري

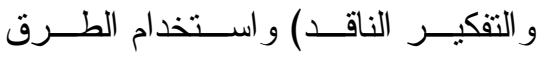
و الاستر اتيجيات الحديثة التـي تراعـى وانس نتوع أساليب التفكير

•. الحرص على تـشجيع الطلبــة علـى لـى

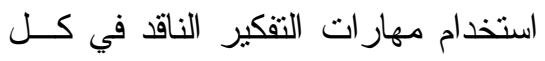

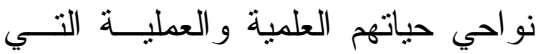
تدعم وتساعد علـى حـلـ المـشكلات و اتخاذ القرار ات.

•. ضرورة التكامل بين المؤسسات التربوية

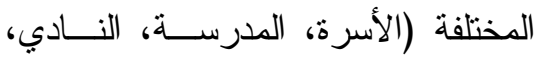

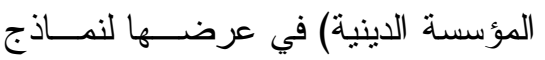

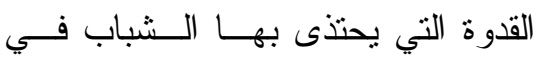

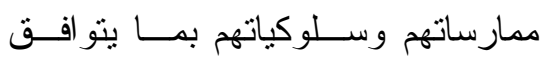
و السلوك الأخلاقي القويم. • . ضرورة الاهتمام بفئات الطلبة من ذوي التفكير الابتكاري المرتفع وكــللك ذوي

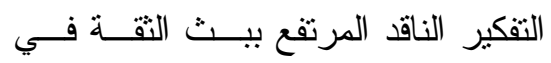
نفوسهم و الرفع من معنوياتهم لاســتثمار

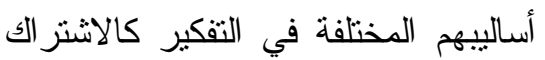
في مسابقات ثقافية للوصول إلى أفـضل أداء لديهم.

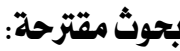

كeniz\& Polat كبير في تشكيل مو اقف وقرار ات الفرد و ادئه السلوكي، فالاشخاص يتصرفون ويفكـرون وفقاً لقبمهم و اخلاقهم الثخصبة.

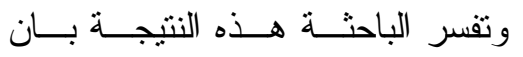

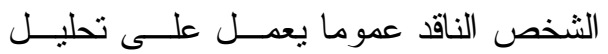

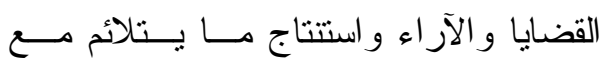
معاييره وتوجهاته القيمية التي تعبـر عـن مكنون ذاته، ويكون لدية القدرة على بلــورة الاستتناجات وحل المشكلات بطريقة عقلانية للتغلب عليها بنجاح من خلال ما يمتلك مسن قيم واخلاقيات تضبط سلوكه وتقومسـه فــي مو اقف الحياة، وبالتالي قدرته علـى اتخــاذ

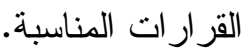

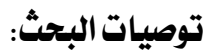

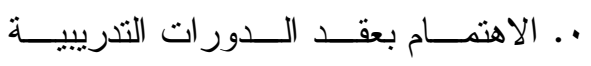
و الندوات التوعوية لنشر وتتعزيز القـيم بهية الأخلاقية وضرورة التمسك بها في ظل

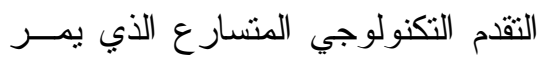
به العالم حاليا. • . توجيــــهـ المعلمـــين للاســـتر اتيجيات و الأنشطة التي تتتاسب مــع مـسنتويات الطلبة ممن لديهم مستويات مرتفعة من التفكير الابتكاري بإعطاء الطلبة تكليفات

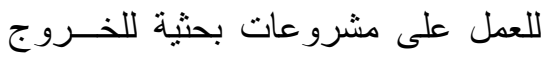

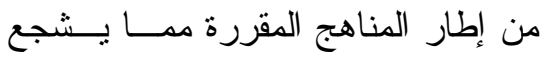
الطلبة على البحث العلمي الذاتي. 
المُناخ الأخلاقي و التفكير الابتكـــاري فـي ظل مدركات الرضا عن الآجر : دراســـة

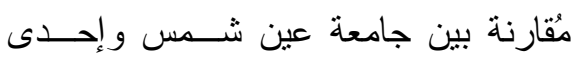
الجامعات الخاصة، المجلة العلمية للبحوث و الدر اسات التجارية، ع (ץ) ديسمبر • - روبرت ماز انو( ع . . ب). ابعـاد التفكيــر إطار عمل للمــنهج وطــرق التــديس، ترجمة: يعقوب حسسين نـشـوان، ط(ب)،

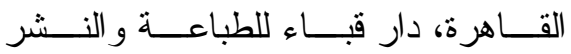
و التوزيع.

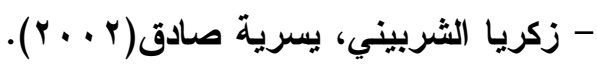
أطفال عند القمة (الموهبة و التفوق العقلـي لئي و الابداع)، القاهرة، دار الفكر العربي.

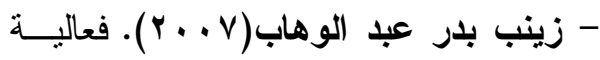
برنامج مقترح في تتمية التفكير الناقد فــي مادة علم الاجتماع لدى الطالبات المعلمات بكلية البنات، رسالة دكتور اه غير منشورة، كلية البنات، جامعة عين شمس لبان

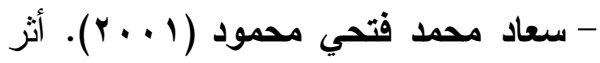
استخدام استر اتيجيات ما ور اء المعرفة في

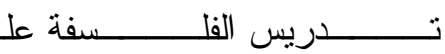

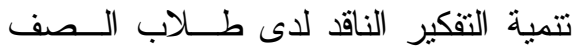
الاول من المرحلـــة الثانويـــة، الجمعيـــة

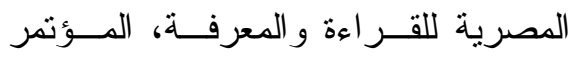

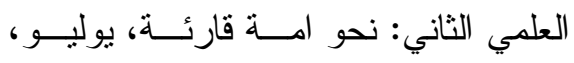

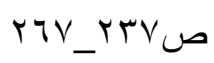

• . نموذجة العلاقة بـين النـسق القيمـي

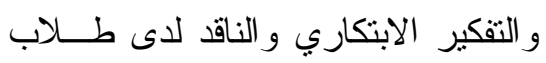

$$
\text { المرحلة الثانوية. }
$$

•. . أساليب التفكير و علاقتها بالقيم الأخلاقية

$$
\text { لدى طلاب المرحلة الثانوية. }
$$

•. . أثز التقاعــل بــين المنظومـــة القيميـــة

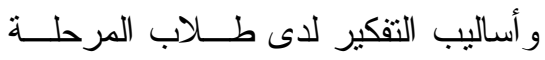

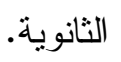

• . تباين القيم الأخلاقيــة بتبــاين أســاليب

$$
\text { التفكير المختلفة. }
$$

اولا :المراجع العربية

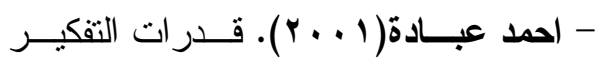

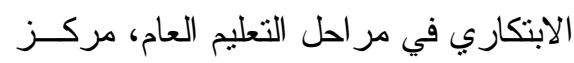

$$
\text { الكتاب للنشر ، القاهرة. }
$$

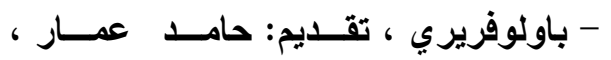

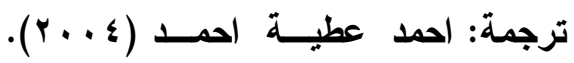

تربية الحرية: الاخلاق -الديموقر اطيــة الثجاعة المدنية، الدار المصرية اللبنانيــة للطباعة و النشر ، القاهرة.

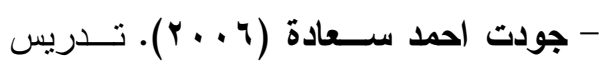

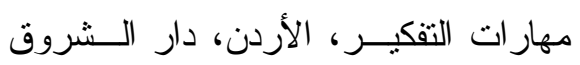
للنشر و التوزيع.

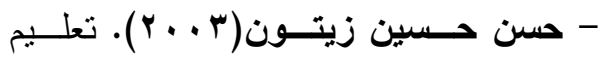
التفكير كروية تطبيقية في تتميــة العقــول

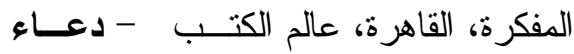
ممدوح محمد شلبي (11 ـ ب). العلاقة بين 
كلية التربية، جامعة البحــرين، مــج(Y)،

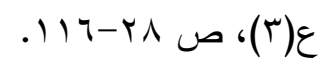

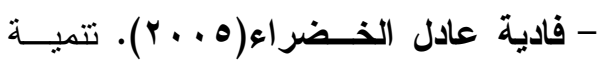

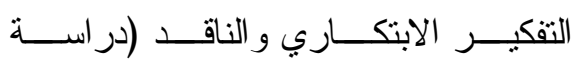

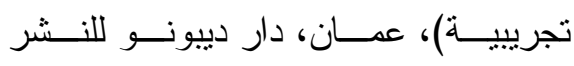

$$
\text { و التوزيع. }
$$

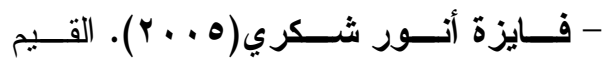

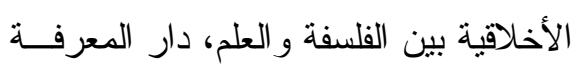

$$
\text { الجامعية، الإسكندرية. }
$$

- فائزة محمــد عبـــ الوهــاب (9V9 ( ) ).

العلاقة بين القدرة على التقكير الابتكــاري

وبعض القيم لاى طلبة المرحلة الثانوية في لاني

الجمهورية العر اقية، رسالة دكتور اه ، كلية

التزبية جامعة المنصورة

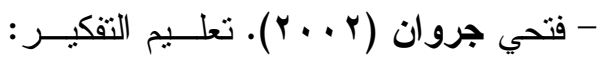

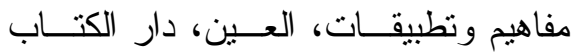

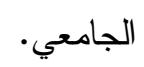

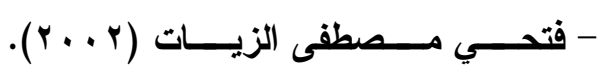

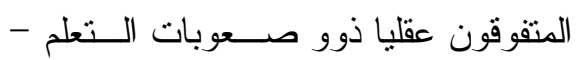

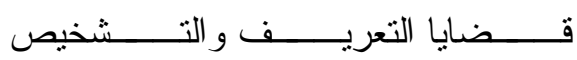

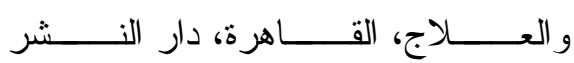

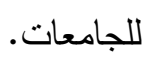

- ماجد زكي الجلاد(0 . . ץ). تعلــم القـيم

وتعليمها (تصور نظري وتطبيعي)، عمان، دان،

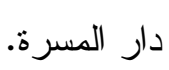

- صلاح الــدين عرفــة (ى ...ب). تعلــيم

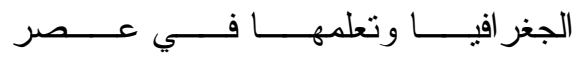
المعلومات، القاهرة،عالم الكتب.

- صفاء يوسف الاعسر( . . . ب). الابــداع في حل المشكلات، القاهرة، دار قباء.

- صلاح الدين عرفــة محمــود (؟ . . ץ). تفكير بلا حدود:رؤى نربوية معاصرة في

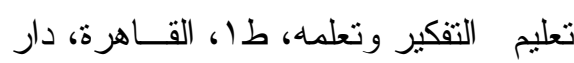
الكتب.

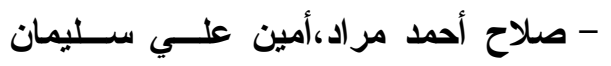

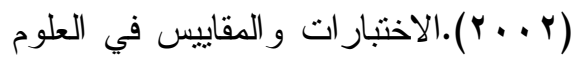

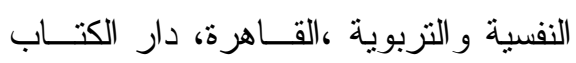

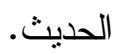

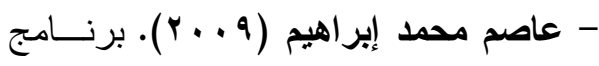
مقتــر ح فــي تــدريس بعــض القـــايا البيو اخلاقيــــــة قـــائم علــــــى الـــــــلملم المنظم ذاتيا و اثرة فى التتميـــة التحــصيل

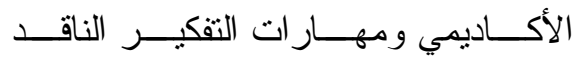
و اخلاقيات العلم لاى طلاب شعبة العلــوم

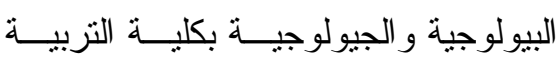
بسو هاج، (دكتور اة) -جامعة سو هاج. كلية التزبية. قسم مناهج وطرق تدريس. - عباس اديبي(1 + . r). قـدرات التفكيــر الابتكاري و علاقتها بعـادات الاســتذكار وقلق الاختبار لدى طلاب التعليم الثـانوي و الجامعي، مجلة العلوم التربوية و النفسية، 
بمدينة الرياض و علاقته ببعض المتغيرات،

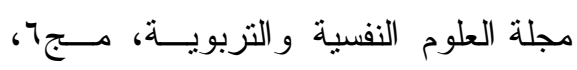

$\cdot(r) \varepsilon$

- محمد عــادل عفيفـي(9A (19). دراســة

تحليلية لمقرر المنطق ودوره فــي تتميــة

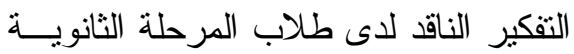

العامة - شعبة الآداب، رسالة ماجستير

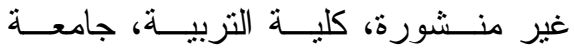

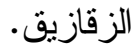

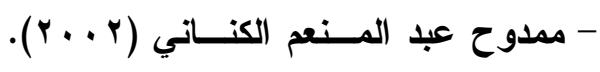
مناخ الابتكارية في الاســرة و المدرســـة،

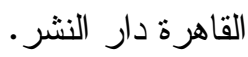

- نادية مصطقى الزقاي ( ( + . ب). القــدرة على التفكير الابتكاري في علاقتها بـالقيم وبعض المتغيــرات الــسيكوسوسيولوجية

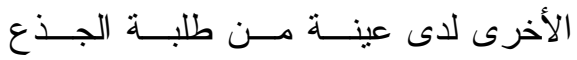
المشترك بمعهد علم النفس جامعة وهران بالجزائر، ع(0 (1)، جامعة ورقلة،الجزائر،

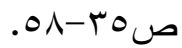

- ناصر نزال شداد(ه . . ب). اثز اســتخدام برنامج لمناقثة القضايا الاسرية في تتمية التقكير الناقد لدى طلاب المرحلة الثانويـــة بدولة الكويت "در اسة تجريبيــة"، رســالة ماجستير غير منشورة، معهد الدراسـات التزبوية، جامعة القاهرة.
- مجدي عبد الكريم حبيب(r . . r). تعلــيم التفكير في عصر المعلومات، القاهرة، دار

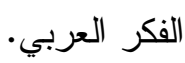
- مجدي عزيز إبراهيم (ه . . ץ). التفكيــر

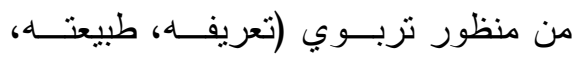
مهار اته، انماطه)، القاهرة، عالم الكتب.

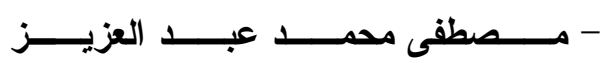

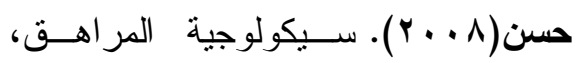
طه، حلوان، مكتبة الانجلو المصرية. - محمد أنـــور إبــر اهيم فــراج (T . . Y).

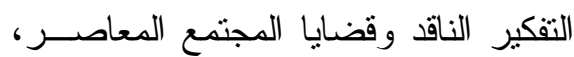
القاهرة، مكتبة الانجلو المصرية.

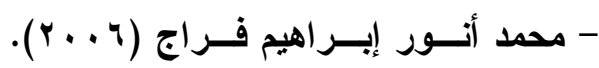
تعريب اختبار كاليفورنيا لمهار ات التفكير الناقد الصورة(أ-ب). - محمد السعيد عبد الحليم(919 1). التفكير

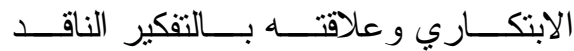

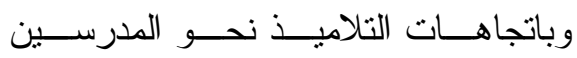
و المدرسات، رسالة دكتور اه غير منشورة، كلية الآداب، جامعة عين شمس. - محمـــد جهــاد جمــل(0 . . ب). تتميـــة

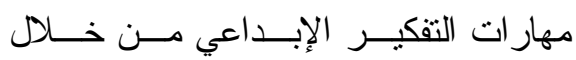

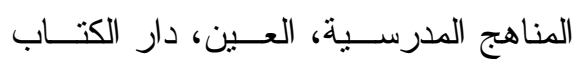

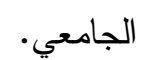
- محمد راثد الثرقي (ه . . ץ). التفكيــر الناقد لدى طلاب الــصف الاول النــانوي 
Can You Have One without the Other?.

- Nalcaci, A. (2012). The Relationship between the Individual Values and Critical Thinking Skills of Prospective Social

Sciences

Teachers. International Journal of Progressive Education, 8(1).

- Napier, J. L., \& Luguri, J. B. (2013). Moral mind-sets: Abstract thinking increases a preference for "individualizing" over "binding" moral foundations.

Social

Psychological and Personality Science, 4(6), 754-759.

- Paul, R. \& Elder. L. (2009). Critical thinking: Ethical reasoning and fair-minded thinking, Part !, Journal of Developmental Education, 1: 3637.

- Pedersen, E. L., \& Burton, K. L. (2009). A concept analysis of creativity: Uses of creativity in selected design journals. Journal

$$
\begin{aligned}
& \text { - وليد محمد أبو المعاطي أبــو المعــاطي }
\end{aligned}
$$

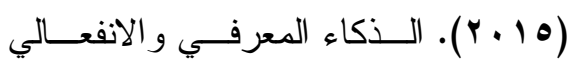

$$
\begin{aligned}
& \text { و الاجتماعي و أساليب التعلم لدى المجودين }
\end{aligned}
$$

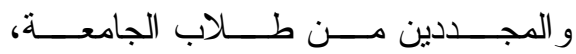

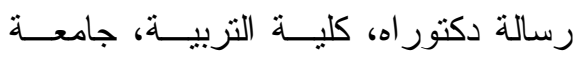

$$
\begin{aligned}
& \text { المنصورة. }
\end{aligned}
$$

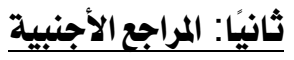

- Antoniou, R. (2015). Moral thinking, creativity, and deception: The paradox of moral thinking.

- Baas, M., De Dreu, C. K., \& Nijstad, B. A. (2008). A metaanalysis of 25 years of moodcreativity research: Hedonic tone, activation, or regulatory focus?. Psychological

bulletin, 134(6), 779.

- Beaussart, M. L., Andrews, C. J., \& Kaufman, J. C. (2013). Creative liars: The relationship between creativity and integrity. Thinking Skills and Creativity, 9, 129-134.

- Fasko Jr, D. (1994). Critical Thinking and Moral Reasoning: 
- pazarı bölümleme. Atatürk Üniversitesi_ktisadi ve _dari Bilimler Fakültesi Dergisi, 22(1), 211-237.

- Menzel, S., \& Bögeholz, S. (2010). Values, beliefs and norms that foster Chilean and German pupils' commitment to protect

biodiversity. International

Journal of Environmental \& Science Education, 5(1), 31-49. of Interior Design, 35(1), 15-32.

- Şahin, S. A., Tunca, N., Altınkurt, Y., \& Yilmaz, K. (2016). Relationship between Professional Values and Critical Thinking Disposition of ScienceTechnology and Mathematics Teachers. Eurasia Journal of Mathematics, Science \& Technology Education, 12(1).

- Ünal, S., Deniz A., \& Polat C. (2008). Marka baglılıg1 ve kisisel degerler açısından 